\title{
PRACTICES OF PERFORMANCE MEASUREMENT IN COMPANIES IN THE REPUBLIC OF SERBIA
}

\author{
Miroslav Todorovic*, Djordje Kalicanin and Aleksandra Nojkovic \\ Faculty of Economics, University of Belgrade, Belgrade, the Republic of Serbia
}

\begin{abstract}
A large number of acronyms which indicate different performance metrics, such as EBIT (Earnings Before Interest And Taxes), EBITDA (Earnings Before Interest, Taxes, Depreciation, And Amortization), ROIC (Return On Invested Capital), NPV (Net Present Value), EVA (Economic Value Added), IRR (Internal Rate Of Return), ROE (Return On Equity), ROA (Return On Assets) etc. are in use nowadays. In practice, managers cannot and do not want to apply all of these metrics and managers' choice does not necessarily rely on what theory emphasizes as their advantages and disadvantages. We surveyed 64 CFOs in order to explore the corporate practice in the Republic of Serbia. The DCF-based capital budgeting metrics are dominant compared to the traditional metrics, and the one that is used the most is the profitability index, only to be followed by the IRR and the NPV. The Payback Period is yet frequently used. The earnings-based corporate performance metrics are still the most important. However, the presence of EVA and balanced scorecard is not negligible. Large companies use them significantly more than small companies. The orientation towards EVA and balanced scorecard increases with the internationalization of a firm as well. Finally, companies using sophisticated capital budgeting metrics are prone to using sophisticated corporate performance metrics.
\end{abstract}

Keywords: performance measurement, capital budgeting metrics, corporate performance metrics

\section{INTRODUCTION}

All decisions of a company can be classified into three categories: strategic, tactical and operational. Strategic decisions concern the business portfolio, the level of the vertical integration and markets in which the company will run its bu-sinesses. Tactical decisions relate to investment projects (i.e. capital budgeting)

\footnotetext{
* Correspondence to: M. Todorovic, Faculty of Economics, University of Belgrade, Kamenicka 6, 11000 Belgrade, the Republic of Serbia; e-mail: todorovic@ekof.bg.ac.rs
}

that implement a pre-formulated strategy. Operational decisions are made in daily operations for the purpose of the implementation of approved projects and business plans. The ultimate criterion in all decisions should be the maximization of the company value.

In a simplified interpretation, all decisions should be directed toward improving a company's performance. In order to improve performance, it is necessary to choose the measures or metrics that will credibly indicate the level of its achievement. Hence the great importance of performance measures - since what 
can be measured can be managed, too. They are clear guidelines in the planning, implementation and control of a business strategy, projects and daily operations. Measurement should not be an end in itself; it should have some meaning - it should indicate the quality of the goal achievement as well as the company's ability (or inferiority) to achieve these goals. A comprehensive and coherent structure of performance measures is called the performance measurement system - the PMS.

Today, a large number of metrics are used in textbooks on corporate finance, strategic management and strategic finance, not only for the measurement of companies' performances - corporate performance metrics - the CPM, but also for the evaluation of investment projects - capital budgeting metrics - the $\mathrm{CBM}^{1}$. Capital budgeting can be seen as a separate methodology, and, in a specific way, also as an integral part of the PMS enabling the creation of the shareholder value. Capital budgeting and the PMS can be said to represent the connecting point of corporate finance and strategic management systems making the cornerstone of strategic finance. Relying on the projected future costs and benefit, the CBM represent a kind of expected or ex ante metrics, while the CPM stand for the ex post measures of the achievement. In business practice, managers cannot and do not want to apply all available metrics and their selection process does not necessarily rely on the theoretical advantages and disadvantages of different metrics.

The aim of this research is to gain an insight into the presence of different performance metrics in companies in Serbia in order to contribute to the narrowing gap between the theory and practice of corporate finance. The research was conducted by surveying managers of 64 companies in the Republic of Serbia (RS), in the period from March to September 2014. This research of ours included a wide range of companies with different characteristics in terms of their size, industry, leverage level, degree of diversification and internationalization etc. Alongside a general insight into the usage of various measures, this allowed us to gain an insight into possible differences in practices between companies with different characteristics, e.g. between large and small companies, public corporations and private companies, diversified and undiversified companies etc. Based on the aim of the research, three hypotheses were tested:

H1: The Discounted-Cash-Flow-based metrics are dominant in capital budgeting in companies in Serbia;

H2: The presence of the sophisticated corporate performance metrics and the performance measurement systems is not negligible;

H3: The characteristics of the companies determine the presence of particular performance measures in practice.

This paper is organized as follows. The next section introduces the theoretical background and the literature review with respect to these subjects of study. Then, an overview of the research methodology is presented. Finally, the results are discussed and several conclusions are made.

\section{THEORETICAL BACKGROUND AND LITERATURE OVERVIEW}

The PMS are formalized, information-based routines and procedures that managers use in maintaining or changing the direction of the business (Simons, 2000, 4). It is recommended that metrics should pass three tests before being included in the PMS (Simons, 2000, 234-240):

- they should be in line with the strategy,

- they should be objective and

- they should be aligned with the supreme aim of maximizing the enterprise's value.

The measures can be identified as Key Results Indicators - the KRIs, in the case of past achievements, or Key Performance Indicators - the KPIs, in the case of the possibilities and capabilities of the company to achieve its goals in the future (Parmenter, 2007). In this way, it is emphasized that a comprehensive PMS should be facing both ex ante and ex post. Also, a comprehensive PMS should include both financial and non-financial performance measures (Kaplan 
\& Norton, 1992; Niven, 2006). The lack of the PMS can have very negative effects on the formulation and implementation of a business strategy (Micheli, Mura \& Agliati, 2011). These assumptions were used to develop a comprehensive PMS called Balanced Scorecard - the BSC (Kaplan \& Norton, 1992; 1996). That PMS integrates in one framework the whole structure of objectives and their measures, targets and initiatives enabling their achievement. Objectives, measures, targets and initiatives can be included in one of the next perspectives: the financial perspective, the consumer perspective, the perspective of internal business processes and the learning and growth perspective. A special advantage of this system is its being derived from the strategy map - a graphically described business strategy (Kaplan \& Norton, 2000).

The traditional system of performance was predominantly based on accounting metrics (Net Profit, Earnings Per Share - the EPS, Earnings Before Interest and Taxes - EBIT, Return on Assets - the ROA, Return on Equity - the ROE etc.) and on the traditional CBM such as the Payback Period - the PP and the Accounting Rate of Return - the ARR. With a further development of corporate finance, the CBM based on the Discounted Cash Flow - the DCF, such as the Net Present Value - the NPV, the Internal Rate of Return - the IRR and the Profitability Index - the PI come to life. Finally, respecting the request of the owners (shareholders) to maximize the value of their stakes in companies, the concept and methodology of ValueBased Management - the VBM - was created. The vanguard of the VBM is the value-based performance measurement (Kaličanin, 2005). There was a sporadic development of these metrics in the second half of the twentieth century; however, their full development and usage started in the last few decades of the twentieth century. Some of the most famous CPM developed in those years were based on the market value of companies or on the concept of the economic profit or on the discounted cash flow such as the Market Value Added - the MVA, the Economic Value Added - the EVA, Residual Income, Cash Flow Return on Investment - the CFROI, the Shareholder Value Added - the SVA, the Cash Value Added - the CVA, Excess Return, the Future Growth Value - the FGV etc. EVA is world-wide expected to be one of the most popular VBM measures. On the other hand, the BSC is the framework for describing value-creating strategies (Speckbacher, Bischof \& Pfeiffer, 2003). These metrics are seen as complementary ones. The BSC should lead to value creation explicitly shown by EVA. Also, EVA could be used as one of the financial metrics in a BSC formulation. Therefore, the contemporary PMS usually include not only accounting metrics but also valuebased performance metrics rather than only financial as well as non-financial metrics.

Empirical researches into corporate finance have generally been rare in Serbia, the region, Central and Eastern Europe and developing countries in general. On the other hand, most of the researches in the US, Western Europe and other developed countries are based on samples with a large number of companies using historical data from financial statements (book values), financial markets (market values) or the intersection of these two sets of data. The advantages of such researches are in the good statistical design and reproducibility of results because of the big size of the samples and the good availability, reliability and objectivity of historical data from financial statements or financial markets. The major drawback of these studies is that one can hardly conclude how financial managers in business practices actually make decisions. This aspect can be explored only through field studies.

It is interesting to note that, after sporadic and relatively poorly observed researches in the last century (e.g. Lintner, 1956; Moore \& Reichert, 1983; Jog \& Srivastava, 1995; Pike, 1996; George \& Chong, 1998; Kester, Chang, Echanis, Haikal, Isa, Skully, Tsui \& Wang, 1999), the first field study which drew academics' attention was published by J. R. Graham and C. R. Harvey (2001) no sooner than in 2001. In this famous study, these two authors collected 392 responses from financial managers of companies on over 100 questions in the survey about capital budgeting and financial decisions. The aim of this study was to elucidate to what extent the practice of corporate finance (decisions that managers make) coincided with the theories of corporate finance (what they learned at university). The overall conclusion of the study was that practice significantly deviates from theory, especially in the domain of the capital structure, but also in the domain 
of capital budgeting. After this study, a number of later studies sought to confirm or deny the GrahamHarvey finding or to analyze the practice from new perspectives (Ryan \& Ryan, 2002; Sandahl \& Sjögren, 2003; Brounen, De Jong \& Koedijk, 2004; Lazaridis, 2004; Dedi \& Orsag, 2007; Truong, Partington \& Peat, 2008; Verma, Gupta \& Batra, 2009; Baker, Dutta \& Saadi, 2011; Correia, 2012; Andrés, Fuente \& San Matin, 2014).

To our best knowledge, no wider field studies on the use of performance metrics in corporate practice in Serbia have been conducted so far. Based on the content of domestic academic textbooks (Kaličanin, 2006; Todorović, 2010; Ivanišević, 2012; Djuričin, Janošević \& Kaličanin, 2013), one could get the impression that, as early as at university, managers acquire sufficient knowledge that investment projects should be evaluated before their execution and, because of their obvious superiority, it is thought that managers ought to use only the DCF CBM, especially the NPV. Additionally, they should use the valuebased CPM, especially EVA, as well as the complex and multidimensional technique of the BSC. In the absence of empirical research in Serbia, the possibility that managers of domestic companies still do not behave in this "expected manner" was in the domain of a "reasonable doubt".

\section{THE RESEARCH METHODOLOGY}

The main objective of the study was to contribute to the narrowing gap between the theory and practice of corporate finance, with a focus on the use of performance metrics. The starting point was the consideration of the extent to which theoretical concepts are actually applied by the managers in business practice. In this sense, the managers of 64 companies were surveyed. Our study included a relatively wide range of companies with different characteristics in terms of their size, industry, listing status, leverage level, degree of diversification and internationalization etc. Apart from our gaining a general insight into the usage of various measures, this also allowed us to gain an insight into possible differences in practices between companies with different characteristics, for example, between large and small companies, public corporations and private companies, diversified and undiversified companies etc.

The survey was conducted between March and September 2014, by collecting responses to the survey with Chief Financial Officers - the CFOs (or Chief Executive Officers - the CEOs) of the companies. In order to determine how various companies' characteristics affect their practice of performance measurement, all firms in the sample were divided into seven sets of two subsamples. The sample overview is given in Table 1.

Twenty-eight companies (or $43.7 \%$ of the total number) were classified as large companies (L) with revenues of more than EUR 10 million $^{2}$. The average revenue per company in the sample was EUR 40.08 million, and the average total asset was EUR 53.73 million. More than half of the companies in the sample (51.56\%) belonged to the food and beverage industry $(\mathrm{F})$. The majority of the companies $(70.31 \%$ ) had sold abroad (I). The eighteen companies were included in the diversified companies (D) that operated in three or more industries and/or generated more than $5 \%$ of

Table 1 Sample characteristics

\begin{tabular}{|c|c|c|c|c|c|c|c|c|c|c|c|c|c|c|c|}
\hline & \multirow{3}{*}{ Sample } & \multicolumn{14}{|c|}{ Groups } \\
\hline & & \multicolumn{2}{|c|}{ Size } & \multicolumn{2}{|c|}{ Industry } & \multicolumn{2}{|c|}{ Internation. } & \multicolumn{2}{|c|}{ Diversific. } & \multicolumn{2}{|c|}{ Leverage } & \multicolumn{2}{|c|}{ Public } & \multicolumn{2}{|c|}{ Profitability } \\
\hline & & $S$ & L & 0 & $\mathrm{~F}$ & $\mathrm{~N}-\mathrm{I}$ & I & UnD & D & UnL & Lev & $\mathrm{N}-\mathrm{P}$ & $P$ & LP & $\mathrm{HP}$ \\
\hline No. & 64 & 36 & 28 & 31 & 33 & 19 & 45 & 46 & 18 & 41 & 23 & 53 & 11 & 37 & 27 \\
\hline$\%$ & 100 & 56.25 & 43.75 & 48.44 & 51.56 & 29.69 & 70.31 & 71.88 & 28.13 & 64.06 & 35.94 & 82.81 & 17.19 & 57.81 & 42.19 \\
\hline
\end{tabular}

Source: Authors 
their revenue from non-core businesses. We classified 23 companies as the leveraged companies (Lev), with the total debt ratio (short-term and long-term debts) in the total resources above $30 \%$. The majority of the companies (85.81\%) were not listed (N-P) in Belgrade or any other stock exchange. Twenty-seven companies were classified as profitable companies (HP), with the ROA (net earnings to total assets) greater than $5 \%$.

In the area of the CBM, the following modalities were offered to managers: 1) the NPV, 2) the IRR, 3) the Profitability Index - the $\left.\mathrm{PI}^{4}, 4\right)$ the Payback Period - the PP, 5) the Discounted Payback Period - the DPP 6) the Accounting Rate of Return - the ARR. All the CBM, especially the DCF CBM, could be calculated using different sets of estimates. In this regard, managers were asked whether they calculated capital budgeting metrics exclusively with the use of one set of inputs (estimates) or different sets of inputs - scenarios (such as "good", "average" and „bad") - a scenario analysis or otherwise tested the impact of changes in certain inputs on a certain metric - a sensitivity analysis. Within the CPM part of the survey, the respondents were offered the following options: 1) the accounting earnings (net profit, EBIT, EBITDA etc.) as absolute indicators, 2) the accounting rates of return (ROE, Return on Invested Capital - the ROIC, the ROA etc.) as relative indicators, 3) EVA and 4) the BSC. The frequency of the use of different metrics in business practice was examined using a 5-point Likert scales (1-never, 5-always). In order to detect any statistically significant differences in the practices of using different metrics between companies with different characteristics, we ran a t-test to compare the mean values of the two samples 5 .

The limitation of this type of research is that the attitudes, beliefs and opinions of the managers examined are not necessarily the way they actually behave when making business decisions. To avoid this drawback, managers were asked to confirm the acceptance and usage of different metrics in their business practices, not their views on the advantages and/or disadvantages of such metrics. Also, we asked the surveyed managers to be honest in their answers (since individual results regarding their companies would not be published). However, we were not in a position to see how honest they really were and what the actual adoption of the various performance metrics in business practice was like. Because of that, in order to improve the reliability of the responses, we collected data on the registration number and used this information to collect additional information about the size of the companies, the leverage and their profitability. The publicly available data from The Serbian Business Registers Agency were used for such purposes.

\section{RESULTS AND ANALYSIS}

The results of the study are presented in two sections, each relating to one of the previously noticed metrics area - the CBM and the CPM. The percentage of the companies which used (always - 5 or almost always 4 on the Likert scale) the given metrics are accounted in the tables. The tables also contain the descriptive statistics, precisely group the means and the p-value indicated as: ${ }^{* * *}, * *, *$ significant difference at the 0.01 , 0.05 , and 0.10 level, respectively.

\section{Capital Budgeting Metrics}

Our first focus was to find out the frequency of the use of different $C B M$. The survey results are shown in Figure 1.

A somewhat surprising finding is that exactly threequarters of the companies always or almost always used the profitability index, as well as the payback period in the same percentage $(75 \%)$. A potential explanation for the high ranking of the PI (more weakly ranked in the textbooks) may be the managers' desire to use the relative metric for which the textbooks emphasized that the same had fewer defects rather than the "relative" IRR. Some earlier studies (Graham \& Harvey, 2001) also revealed managers' tendency to use "percentage" and relative metrics; in this case, however, it was the IRR ${ }^{6}$. According to the results of our study, the IRR was also highly used (63.9 $\%)$, but only in the third place, being preceded by the PI and the PP. The Payback Period was highly ranked, likely because of its simplicity and understandability. Because managers largely use the DCF metrics for the investment project evaluation, we believe that the 


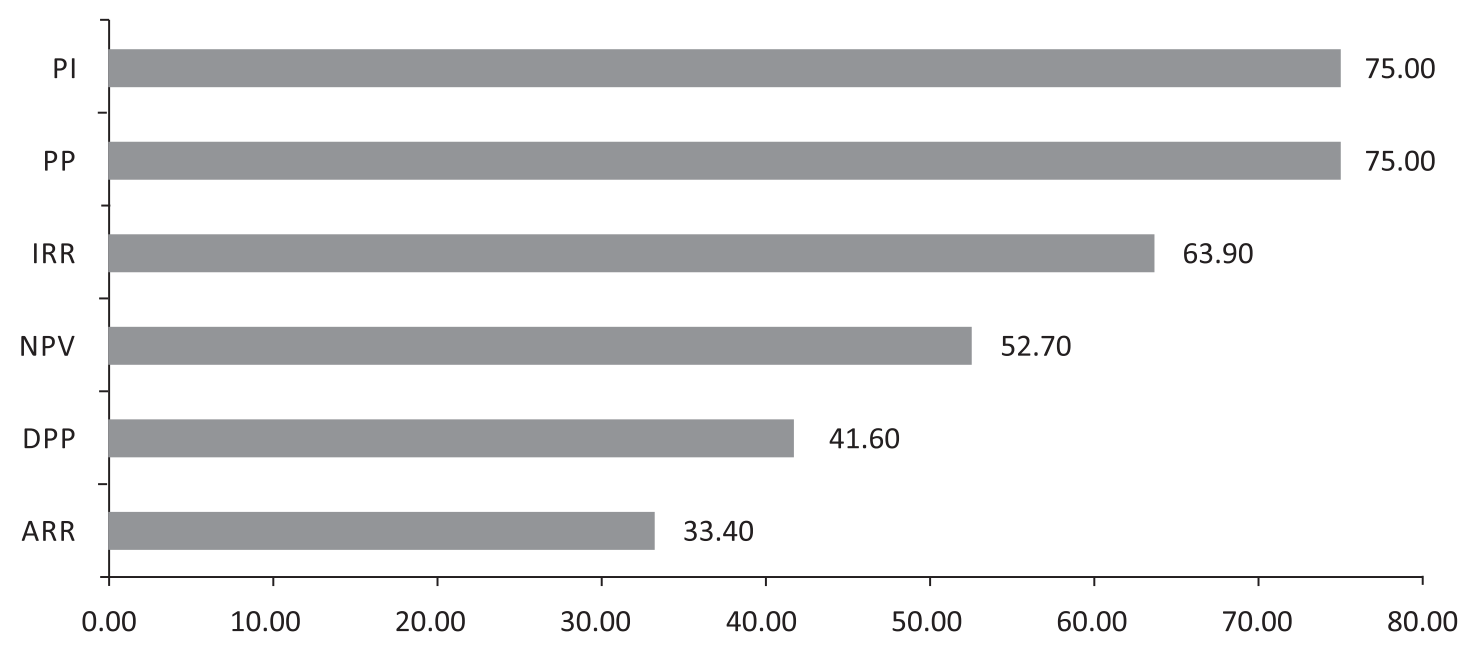

Figure 1 The percentage of the respondents who always or almost always use the given CBM

Source: Authors

Payback Period is used as an additional metric, which certainly should not be seen as a big mistake. Although the textbooks devote far more space to the NPV, emphasizing its superiority, we have shown that this method was not the most widely used one in business practice. Only slightly more than half of the managers (52.7\%) used this method always or almost always in the evaluation of investment projects. An encouraging result of our study was that the DCF metrics were considered to be more important than the non-DCF method, which is similar to the finding of Kester's et al. (1999). Only $8.3 \%$ of the surveyed managers did not use any of the DCF metrics - the NPV, the IRR or the PI - they rather used the traditional CBM instead. About $19 \%$ of the total number of the companies used only the DCF metrics. The remaining part of the sample, i.e. about $73 \%$ of the companies, used a combination of the traditional and the DCF metrics. Another encouraging result of our research was that the DPP and the ARR were the least present metrics. Since these metrics are not characterized by a kind of qualities, we can conclude that it is good that their adoption was low.

The main difference in our findings in relation to the previous research does not lie in the high rating of the PP (and the IRR) but in the excellent ranking of the PI. Our results support G. Truong et al (2008), who concluded that, in Australia, projects were usually evaluated using the NPV, the IRR and the PP, and S. Verma et al (2009), with very similar results, but on the corporate practice in India. Our findings slightly differ from the finding of the study conducted by L. Dedi and S. Orsag (2007) in Croatian firms, who found out the following priority list of metrics: 1) the IRR (59\%), 2 ) the PP (56\%) and 3) the NPV (42\%). There is also a slight difference in relation to Spain, where the most favored metric was the PP, which was followed by the IRR and the NPV (Andrés et al, 2014). The PP was the most preferred metric in Cyprus as well (Lazaridis, 2004). Besides, our study cannot support the results of H. K. Baker et al (2011), who found out that, in Canada, there was a strong preference for the NPV followed by the IRR and the PP. We found out that the IRR was preferred over the NPV, which is also contrary to the findings of P. A. Ryan and G.P. Ryan (2002), who found out in their survey of Fortune 1000 companies that the NPV was preferred over the IRR and other capital budgeting metrics. Finally, having in mind that less than $10 \%$ of the companies did not use the DCF metrics, we can point out that, in RS, the DCF metrics have become a norm, such as that shown by V. M. Jog and A. Srivastava (1995) in the case of Canadian firms.

We further explored whether the use of metrics differs across firms' sizes, industry, profitability, leverage etc. The survey results are shown in Table 2. 
Table 2 The frequency of the use of the different CBM

\begin{tabular}{|c|c|c|c|c|c|c|c|c|c|c|c|c|c|c|c|c|}
\hline \multirow{3}{*}{ Metric } & \multirow{3}{*}{ \% use } & \multirow{3}{*}{$\begin{array}{l}\text { All } \\
\text { Mean }\end{array}$} & \multicolumn{14}{|c|}{ Mean } \\
\hline & & & \multicolumn{2}{|c|}{ Size } & \multicolumn{2}{|c|}{ Industry } & \multicolumn{2}{|c|}{ Internation. } & \multicolumn{2}{|c|}{ Diversific. } & \multicolumn{2}{|c|}{ Leverage } & \multicolumn{2}{|c|}{ Public } & \multicolumn{2}{|c|}{ Profitability } \\
\hline & & & $S$ & L & 0 & $\mathrm{~F}$ & $\mathrm{~N}-\mathrm{I}$ & I & UnD & D & UnL & Lev & $N-P$ & P & LP & HP \\
\hline NPV & 52.70 & 3.56 & 3.31 & 3.75 & 3.92 & 3.35 & 2.63 & $3.82^{* *}$ & 3.36 & 4.00 & 3.25 & 3.94 & 3.34 & $4.43^{* *}$ & 3.58 & 3.50 \\
\hline IRR & 63.90 & 3.89 & 3.56 & $4.15^{*}$ & 3.77 & 3.96 & 3.38 & 4.04 & 3.72 & 4.27 & 3.80 & 4.00 & 3.83 & 4.14 & 3.92 & 3.83 \\
\hline $\mathrm{Pl}$ & 75.00 & 3.89 & 3.81 & 3.95 & 3.54 & 4.09 & 3.63 & 3.96 & 3.64 & $4.45^{*}$ & 3.70 & 4.13 & 3.79 & 4.29 & 4.04 & 3.58 \\
\hline PP & 75.00 & 4.08 & 3.75 & 4.35 & 4.15 & 4.04 & 3.50 & $4.25^{*}$ & 4.00 & 4.27 & 4.05 & 4.13 & 4.00 & 4.43 & 4.00 & 4.25 \\
\hline DPP & 41.60 & 3.17 & 2.81 & 3.45 & 2.85 & 3.35 & 2.50 & 3.36 & 3.08 & 3.36 & 3.10 & 3.25 & 3.00 & 3.86 & 3.21 & 3.08 \\
\hline ARR & 33.40 & 2.97 & 2.94 & 3.00 & 2.62 & 3.17 & 2.75 & 3.04 & 2.92 & 3.09 & 2.90 & 3.06 & 3.00 & 2.86 & 3.04 & 2.83 \\
\hline
\end{tabular}

Source: Authors

We found several statistically significant differences between different groups of companies. The managers of the large and listed companies were loyal to these metrics of the "old school" - the NPV and the IRR; the public (listed) companies used the NPV to a significantly greater extent than the private companies (4.43 vs. 3.34) and the large companies used the method of the IRR significantly more than the small ones (4.15 vs. 3.56). We could assume that, in the case of the listed companies, the managers' perception of the strong pressure of the financial market to earn a return above the WACC was the main reason for higher "loyalty" toward the metrics than the use of the WACC. Furthermore, large and listed companies usually have the greatest percentage of CFOs (and CEOs), with the highest degree in finance. We assume they are keen to apply what they learned at university and apply those metrics that they believe are the most credible ones. The diversified companies used the PI more in relation to the undiversified ones (4.45 vs. 3.64$)$. The reason for this probably lies in the fact that diversification requires more "prudential" metrics in investment decision-making and the PI is a superior method for project ranking and for making a comparison between investment projects in different business units in a multi-businesses company. The internationalization clearly increased the tendency towards the NPV and the PP. Belonging to a particular industry and the company's profitability were irrelevant to the managers' tendency to use different metrics.

Although not at the level of statistical significance, the careful examination of the results in Table 2 can easily reveal a very interesting finding - the tendency towards the use of all the metrics was higher for the large, public ${ }^{7}$, internationalized and diversified companies. Those types of companies (typically wellknown in a small national economy like the Serbian one) usually engage CFOs with sound financial education; they usually have good procedures and staff with better knowledge in financial departments and usually evaluate their investment projects together with specialized consultants in the areas of finance and accounting. In that context, not using the CBM would be surprising. The tendency towards the use of all the metrics was also higher for the leveraged companies. One possible explanation can be found in the disciplining role of a debt that leads to the rigorous investment process. Additionally, it is expected that, in their applications for financial support of banks, those companies must carry out an investment analysis of a higher quality.

In some way, there was a similarity in our results with D. Brounen et al (2004), who stated that managers in large U.S. companies generally preferred the DCF metrics. The same comparison could be made with G. Sandahl and S. Sjögren (2003), who found out that the large companies were the ones to more frequently use the DCF method than the small ones. Again, there is a partial congruence with C. Correia (2012), who found out that those larger companies preferred the DCF metrics, and that the small firms used the PP and the ARR to a greater extent. Our finding, as well as M. G. Danielson and J. A. Scott's finding (2006), that small businesses usually use the DCF metrics more 
rarely than large companies could be explained by the limited education background of the managers in small companies and the small staff size. Interestingly, we can compare the results of our study that showed that the domestic public companies preferred the NPV in relation to H. W. George and T. K. Chong (1998), who found out that the executives of the public companies in Singapore considered the IRR and the PP to be equally important. It is hard to explain the greater tendency of the internationalized companies in Serbia to be using the PP metrics, just as much as it is difficult to explain the greater adoption of this metric in this case of the large companies in Cyprus (Andrés et al, 2014).

Furthermore, we wanted to assess the presence of a scenario and/or sensitivity analysis (SA) in capital budgeting. The results are shown in Table 3.

The evaluation of investment projects was usually done using one set of data and assumptions. However, there are companies $(44.4 \%)$ that sought to take multiple scenarios into consideration. We found that the managers of the large, diversified, leveraged, public and profitable companies had a greater tendency towards the scenario analysis; however, the difference towards the use of the scenario analysis was only statistically significant between the internationalized and the non-internationalized companies (3.32 vs. 2.38). The difference could be explained by different types of risks as a consequence of the internationalization of business operations. There are usually several unknowns about political and legal, economic, sociocultural, technological and ecological factors in a foreign country, as well as unknowns regarding the same industry but in a foreign country. A company can hardly know well all competitive forces as it can do in its domestic market. It is more difficult to predict all important competitors' movements and the dynamics of rivalry, buyers' plans regarding purchasing and the price they might be willing to pay, suppliers' intentions regarding their switching to other partners and the vertical integration and their pricing strategy, the future pressure of substitutes that could come from other industries as well as a threat of new entrants. That is the reason why, in evaluating an investment decision, internationalized firms usually include changes in single or several assumptions about the costs (rising), the selling price (lowering), the project starting date (delaying) and so forth.

\section{Corporate Performance Metrics}

Our second focus was to find out the frequency of the use of different corporate performance metrics - the CPM. More specifically, expecting a predominant reliance on the accounting metrics, we were interested in the presence of EVA (or the economic profit) and the BSC in the companies in Serbia. We obtained the answers shown in Figure 2.

It is not surprising that the absolute measures of the accounting profit were still the most common in the business practice in RS. Over $4 / 5$ of the managers $(82.9 \%)$ relied on them when observing/assessing the company's performance. There was also a relatively high presence of the relative accounting indicators such as ROA, ROE, ROIC etc.; they were in use in about $2 / 3$ of the companies. Comparing to the accounting metrics, there was a sharp difference in the adoption of modern metrics (or the PMS), namely EVA and the BSC. EVA was being used more frequently than the BSC. Seemingly the relatively poorly used EVA was

Table 3 The frequency of the use of a scenario/sensitivity analysis

\begin{tabular}{|c|c|c|c|c|c|c|c|c|c|c|c|c|c|c|c|c|}
\hline \multicolumn{3}{|c|}{ All } & \multicolumn{14}{|c|}{ All } \\
\hline & \multirow{2}{*}{$\%$ use } & \multirow{2}{*}{ Mean } & \multicolumn{2}{|c|}{ Size } & \multicolumn{2}{|c|}{ Industry } & \multicolumn{2}{|c|}{ Internation. } & \multicolumn{2}{|c|}{ Diversific. } & \multicolumn{2}{|c|}{ Leverage } & \multicolumn{2}{|c|}{ Public } & \multicolumn{2}{|c|}{ Profitability } \\
\hline & & & S & L & 0 & $\mathrm{~F}$ & $\mathrm{~N}-\mathrm{I}$ & I & UnD & D & UnL & Lev & $\mathrm{N}-\mathrm{P}$ & $P$ & LP & HP \\
\hline SA & 44.40 & 3.11 & 2.75 & 3.40 & 3.15 & 3.09 & 2.38 & $3.32^{*}$ & 3.04 & 3.27 & 2.95 & 3.31 & 2.97 & 3.71 & 2.96 & 3.42 \\
\hline
\end{tabular}

Source: Authors 


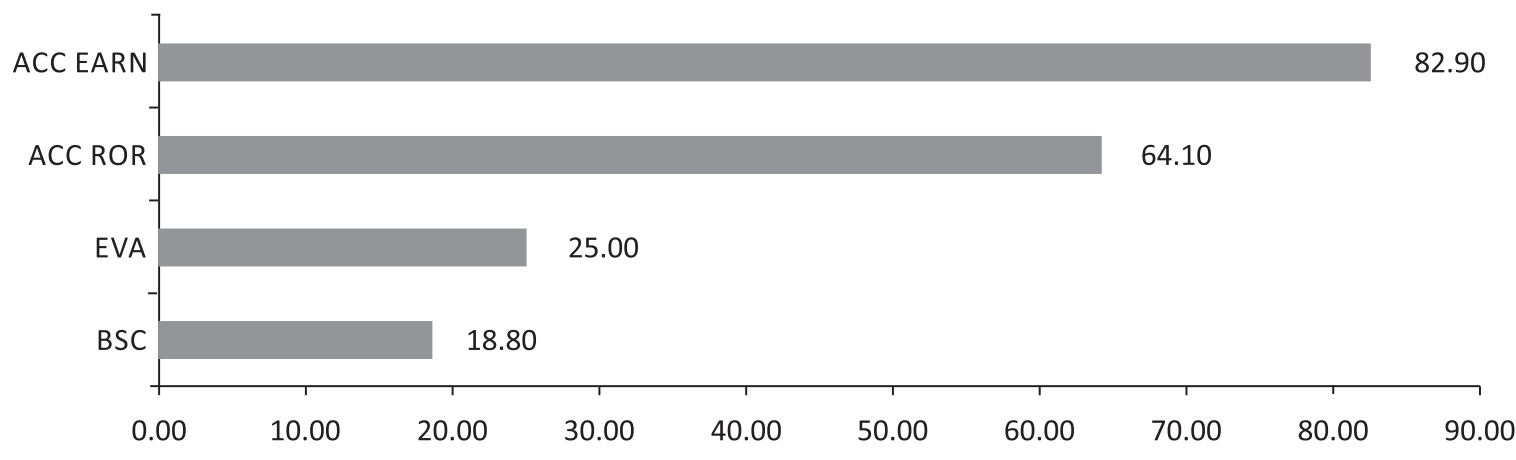

Figure 2 Percentage of respondents who always or almost always used the given CPM

Source: Authors

still present in constant or nearly constant use in $1 / 4$ of the companies. In relation to what had been recorded in the earlier studies conducted in RS (Stančić, Todorović \& Čupić, 2012; Domanovic, 2013), this was an obvious forward. The conclusion that the VBM starts to be not only rhetoric but also supported by a sound methodology can be drawn. Besides, another very encouraging result was the presence of the BSC in a little less than $1 / 5$ of the companies $(18.8 \%)$. There were different forms of the BSC implementation. The simplest only implies a combination of the financial and the non-financial measures; the second type involves the strategy maps and the third one implies linking incentives to the BSC. Due to the design of our study, it was impossible to test which form of the BSC the companies in RS used: at least, however, they used some meaningful mixture of the financial and the nonfinancial metrics. EVA and the BSC are assumed to have been less present because they are less-known, much more complex to use and, as opposed to the accounting metrics, they are not the direct result of the statutory accounting records. Besides, there are still researches into the effectiveness of those metrics. Theoretically, they are almost perfect, but on the other hand, there are many limitations and problems in their practical use. Probably, that imperfection makes many domestic managers unready to try them without demur. Additionally, modern metrics are often promoted by global consulting companies. In RS, excluding auditing, the consulting industry did not attract so many big global players that would promote these metrics. Perhaps there are not enough companies which can financially afford to use them. Namely, the application of those metrics is very often facilitated by a piece of software usually too expensive for domestic companies. Finally, managers are pretty aware of possible fee obligations for patented metrics. All these factors seriously limit its use and make managers more loyal to the accounting metrics.

We continued our analysis by trying to see if there was any difference between the practices in the corporate performance metrics of different groups of companies. The results are shown in Table 4.

The survey results reported in the previous table indicate that the adoption of different metrics varied significantly across the company's size, its level of internationalization and profitability.

EVA was significantly more used in the large companies than in the small ones (the mean of 2.96 vs. 1.78) and in the companies that generated revenues from foreign markets rather than in those that only sold on the domestic market (2.60 vs. 1.58). We found that there was a similar situation when the usage of the BSC was concerned in the large (2.61 for the large ones, 1.92 for the small ones) and internationalized companies (2.40 for the internationalized ones vs. 1.79 for the non-internationalized ones). EVA was least prevalent in the companies that generated revenues solely on the domestic market (the mean of 1.58) and the most common in the large companies (2.96). The 
Table 4 The frequency of the use of different CPM

\begin{tabular}{|c|c|c|c|c|c|c|c|c|c|c|c|c|c|c|c|c|}
\hline \multirow{3}{*}{ Metric } & \multirow{3}{*}{$\%$ use } & \multirow{3}{*}{$\begin{array}{l}\text { All } \\
\text { Mean }\end{array}$} & \multicolumn{14}{|c|}{ Mean } \\
\hline & & & \multicolumn{2}{|r|}{ Size } & \multicolumn{2}{|c|}{ Industry } & \multicolumn{2}{|c|}{ Internation. } & \multicolumn{2}{|c|}{ Diversific. } & \multicolumn{2}{|c|}{ Leverage } & \multicolumn{2}{|c|}{ Public } & \multicolumn{2}{|c|}{ Profitability } \\
\hline & & & $S$ & L & 0 & $\mathrm{~F}$ & $\mathrm{~N}-\mathrm{I}$ & I & UnD & D & UnL & Lev & $N-P$ & P & LP & HP \\
\hline $\begin{array}{l}\text { ACC } \\
\text { EARN }\end{array}$ & 82.90 & 4.31 & 4.00 & $4.71^{* * * *}$ & 4.29 & 4.33 & 4.11 & 4.40 & 4.30 & 4.33 & 4.22 & 4.48 & 4.28 & 4.45 & 4.38 & 4.22 \\
\hline $\begin{array}{l}\text { ACC } \\
\text { ROR }\end{array}$ & 64.10 & 3.61 & 3.11 & $4.25^{* * *}$ & 3.68 & 3.65 & 2.63 & $4.02 * * *$ & 3.54 & 3.78 & 3.46 & 3.87 & 3.58 & 3.73 & 3.95 & 3.15 \\
\hline EVA & 25.00 & 2.30 & 1.78 & $2.96^{* * *}$ & 2.26 & 2.33 & 1.58 & $2.60 * * *$ & 2.30 & 2.28 & 2.32 & 2.26 & 2.36 & 2.00 & 2.49 & 2.04 \\
\hline BSC & 18.80 & 2.22 & 1.92 & $2.61^{* *}$ & 2.1 & 2.33 & 1.79 & $2.40^{*}$ & 2.28 & 2.06 & 2.17 & 2.30 & 2.13 & 2.64 & 2.24 & 2.19 \\
\hline
\end{tabular}

Source: Authors

BSC was mostly used by the listed companies (2.64) and it was also present the least in the companies that earned their income solely on the domestic market (1.79). The somewhat wider acceptance of the BSC by the listed companies could originate from their awareness of the essence of the BSC.

On the basis of the previous results, we could conclude that the sophistication of companies in their orientation towards modern performance metrics increased with the size and the level of the internationalization of the firms. Additionally, we found that the large and internationalized companies were also using more relative accounting metrics than the small and noninternationalized ones. Finally, the large firms were also more prone to using absolute accounting numbers comparing than the small companies. Therefore, the large companies used all the metrics to a significantly greater extent than tge small companies. The wider acceptance of all the metrics in the large companies in comparison to the small companies could be explained by the development of the processes and the quality of the staff at the finance controlling and planning departments in the large companies. The PMS were usually developed at those departments. They represented the central units communicating with many other departments regarding the PMS and its parts and components. A somewhat unusual finding is that the firms with a higher profitability had a tendency to use less relative accounting metrics (3.15 vs. 3.95). The other characteristics of the companies had no influence on the choice of the performance measures.

There are a few studies that were conducted in several countries on the topic of the acceptance of different metrics. The results are variegated and should be taken with a large grain of salt. A research conducted in the USA in 1998 into the EVA acceptance of the Fortune 500 companies revealed that only $9.4 \%$ of the companies specifically stated that they used EVA as a performance measure, as a "trendy" tool (Abdeen \& Haight, 2002). Referring to the research conducted by the Institute of Management Accountants, M. W. Meyer (2004) argues that, in 1995, 18\% of the largest US companies used EVA and in 1996, „34\% of the companies actually used EVA"! According to a survey conducted by the Business Finance Magazine in $2004^{8}, 33 \%$ of the companies used the BSC, whereas $18 \%$ of the companies used EVA. However, the large companies (with revenues of more than $\$ 1$ billion) used the BSC in even $59 \%$ of the cases, and $33 \%$ of them used EVA. G. Speckbacher et al (2003) found that about a quarter of the most important publicly traded firms (26\%) in the German-speaking countries (Germany, Austria and Switzerland) used the BSC, while the majority of them used it in the simplest way. They also noticed that the larger companies (measured as the number of employees) were more likely to use the BSC while the retail industry used this metric significantly less. M. Marc, D. Peljhan, N. Ponikvar, A. Sobota i M. Tekavcic (2010). found that even $68 \%$ of the large Slovenian companies used the BSC or some other 
integrated PMS. However, comparing the results of the two studies conducted in 2003 and 2008, they noticed that the Slovenian companies still preferred financial measures to non-financial ones. Another investigation about the use of the BSC within small companies conducted in the UK and Cyprus (Giannopoulos, Holt, Khansalar \& Cleanthous, 2013) showed that awareness was significantly higher in Cyprus (45\%) than in the UK $(20 \%)$. However, the percentage of the „aware” companies that really used the BSC was the same in both countries $(25 \%)$.

Ultimately, we asked ourselves whether there was a meaningful relationship in the use of the CBM and the use of the CPM. We expected that the companies increasingly using EVA or the BSC also used the DCF metrics more in the area of capital budgeting. The results are presented in Table 5.

Table 5 The simultaneous use of the CBM and the CPM

\begin{tabular}{l|cc}
\hline \multirow{2}{*}{ Metric } & \multicolumn{2}{|c}{ EVA/BSC } \\
& Do not use & Use \\
\hline NPV & 3.36 & 4.00 \\
IRR & 3.76 & 4.18 \\
PI & 3.88 & 3.91 \\
PP & 4.82 & $3.76^{* * *}$ \\
DPP & 3.91 & $2.84^{* *}$ \\
ARR & 2.96 & 3.00 \\
& $\ldots$ & \\
SA & 2.84 & $3.73^{*}$ \\
\hline
\end{tabular}

Source: Authors

The companies that used modern corporate performance metrics also used the DCF metrics (the $\mathrm{NPV}$, the IRR and the PI) to a greater extent, but the difference was not statistically significant. However, these companies used the traditional CBM, namely the PP and the DPP, less to a statistically significant extent. Finally, we also found that the managers of these companies had greater propensity towards a scenario analysis.

\section{CONCLUSION}

Corporate performance metrics and capital budgeting metrics are to be viewed as the complementary subsystems of the performance measurement system. Their development enables comprehensive efforts for directing a company to maximizing its shareholders' (owners') value. We conducted a field study with the two main goals: to see which metrics were used by the managers in the companies in RS and also to see how a company's characteristics influenced such a choice. The main limitation of the field study is that we must assume that the managers are honest in their answers and that they "do what they say they do". Due to a social desirability bias, survey studies generally tend to overstate the adoption of more sophisticated metrics.

Several conclusions can be pointed out. Regarding the first hypothesis, we noticed that the DCF capital budgeting metrics were dominant in the companies in RS. Also, we found out that the managers of the companies in Serbia used the PI and the PP to the greatest extent while the IRR method was preferred over the NPV (which only was not the case with the listed companies). The managers' orientation towards the PI was commendable since the PI takes the most part of the advantages of the NPV and is a relative measure at the same time. Because of their lacking good knowledge of the foreign market, the companies selling abroad tend to use a sensitivity analysis more than the non-internationalized ones. Accounting earning and the accounting rates of return were still more than dominant compared to modern metrics. However, the presence of the modern metric was not negligible, which speaks in favor of the second hypothesis. The large companies were keen to use EVA and the BSC more than the small ones. The small companies used each of all corporate performance metrics significantly less than the large companies. There was an obviously greater adoption of EVA and the BSC across the internationalized companies. Finally, the companies that did not use modern corporate performance metrics and systems 
were also inclined to use significantly more the traditional, non-DCF capital budgeting metrics. The previously described differences in the presence of different metrics across the companies with different characteristics clearly confirmed our third hypothesis.

This study opened possibilities for several future researches. Longitudinal studies are quite a logical (and usual) extension to this kind of research subjects because of the possibility of changing the mentioned practices. Another very interesting thing could be a simultaneous research across the countries in the region because many of the surveyed companies have their subsidiaries in those countries with some autonomy in investment decision making. In the end, a special study can be conducted with the purpose of finding out whether using sophisticated metrics leads to a better financial performance.

\section{ENDNOTES}

1 The term methods of capital budgeting is usually used in the literature; nevertheless, the term capital budgeting metrics can also be found to be in use (Brigham \& Houston, 2012, 400).

2 All quantitative data refer to the day of 31st Dec. 2013 and were collected from the website of The Serbian Business Registers Agency (www.apr.rs).

3 The same threshold was used by J. R. Graham and C. R. Harvey (2001).

4 The profitability index is also referred to as the benefit-cost ratio.

5 We were guided by J. C. F. de Winter and D. Dodou's (2010) conclusion, revealing that the t-test could be used instead of the Mann-Whitney-Wilcoxon test since the two tests had an equivalent power.

6 Besides, this attitude was usually characterized as a wrong orientation because the NPV is described in textbooks as a superior method. Nevertheless, the objection is not apposite since managers do not necessarily remember all the lessons learnt during their studies.

7 Except for the ARR.

8 http://businessfinancemag.com/planning-budgeting-amp- reporting/performance-managements-growing-pains, accessed on the day of 28 th Feb. 2015

\section{REFERENCES}

Abden, A. M., \& Haight, T. G. (2002). A Fresh Look At Economic Value Added: Empirical Study Of The Fortune Five-Hundred Companies. The Journal of Applied Business Research, 18(2), 27-36.

Andrés, P. de, Fuente, G. de, \& San Martin, P. (2014). Capital budgeting practices in Spain. Business Research Quarterly, (Article in press), http://dx.doi.org/10.1016/j.brq.2014.08.002.

Baker, H. K., Dutta, S., \& Saadi, S. (2011). Corporate finance practices in Canada: Where do we stand? Multinational Finance Journal, 15(3/4), 157-192.

Brigham, E. F., \& Houston, J. F. (2012). Fundamentals of Financial Management. Concise Edition, Cengage Learning.

Brounen, D., de Jong, A., \& Koedijk, K. (2004). Corporate finance in Europe: Confronting theory with practice. Financial Management, 33(4), 71-101.

Correia, C. (2012). Capital budgeting practices in South Africa: A review. South African Journal of Economic and Management Sciences, 43(2), 11-29.

Danielson, M. G., \& Scott, J. A. (2006). The capital budgeting decisions of small businesses. Journal of Applied Finance, $16(2), 45-56$.

Dedi, L., \& Orsag, S. (2007). Capital Budgeting Practices: A Survey of Croatian Firms. South East European Journal of Economics and Business, 2(1), 59-67. doi: 10.2478/v10033-0070016-y

de Winter, J. C. F., \& Dodou, D. (2010). Five-point Likert items: $\mathrm{t}$ test versus Mann-Whitney-Wilcoxon. Practical Assessment, Research \& Evaluation, 15(11), 1-16.

Domanovic, V. (2013). The effectiveness of the performance measurement in terms of contemporary business environment. Economic Horizons, 15(1), 33-46. doi:10.5937/ ekonhor1301031D

Đuričin, D., Janošević, S., i Kaličanin, Đ. (2013). Menadžment $i$ strategija. Beograd, Republika Srbija: Ekonomski fakultet.

Graham, J. R., \& Harvey, C. R. (2001). The theory and practice of corporate finance: Evidence from the field. Journal of Financial Economics, 60(2-3), 187-243. doi:10.1016/S0304405X(01)00044-7

George, K. W., \& Chong, T. K. (1998). Capital budgeting 
practices of listed firms in Singapore. Singapore Management Review, 20(1), 9-23.

Giannopoulos, G., Holt, A., Khansalar, E., \& Cleanthous, S. (2013). The Use of The Balanced Scorecard in Small Companies. International Journal of Business and Management, 8(14), 1-22. doi: 10.5539/ijbm.v8n14p1

Ivanišević, M. (2012). Poslovne finansije. Beograd, Republika Srbija: Ekonomski fakultet.

Jog, V. M., \& Srivastava, A. (1995). Capital Budgeting Practices in Corporate Canada. Financial Practice and Education, 5(2), 37-43.

Kaličanin, Đ. (2005). Merenje performansi zasnovano na vrednosti. Ekonomika preduzeća, 53(3-4), 91-100.

Kaličanin, Đ. (2006). Menadžment vrednosti preduzeća. Beograd. Republika Srbija: Ekonomski fakultet.

Kaplan, R. S., \& Norton, D. P. (1992). The balanced scorecard measures that drive performance. Harvard Business Review, 70(1), 71-79.

Kaplan, R. S., \& Norton, D. P. (1996). The Balanced Scorecard: Translating Strategy into Action. Boston, Massachusetts: Harvard Business School Press.

Kaplan, R. S., \& Norton, D. P. (2000). Having Trouble with Your Strategy? Then Map It! Harvard Business Review, 78(5), 167176.

Kester, G., Chang, R. P., Echanis, E. S., Haikal, S., Isa, M. Md., Skully, M. T., Tsui, K. C., \& Wang, C. J. (1999). Capital budgeting practices in the Asia-Pacific region: Australia, Hong Kong, Indonesia, Malaysia, Philippines, and Singapore. Financial Practice and Education, 9(1), 25-33.

Lazaridis, I. (2004). Capital budgeting Practices: A survey in the Firms in Cyprus. Journal of Small Business Management, 42(4), 427-433. doi: 10.1111/j.1540-627X.2004.00121.x

Lintner, J. (1956). Distribution of incomes of corporations among dividends, retained earnings, and taxes. The American Economic Review, 46(2), 97-113.

Marc, M., Peljhan, D., Ponikvar, N., Sobota, A., \& Tekavcic, M. (2010). Performance Measurement in Large Slovenian Companies: An Assessment of Progress. International Journal of Management \& Information Systems, 14(5), 129-139.

Meyer, M. W. (2004) Finding performance: The new discipline in management, In A. Neely (Ed.). Business performance measurement: Theory and practice (pp. 113-124). New York, NY: Cambridge University Press.
Micheli, P., Mura, M., \& Agliati, M. (2011). Exploring the roles of performance measurement systems in strategy implementation: The case of a highly diversified group of firms. International Journal of Operations $\mathcal{E}$ Production Management, 31(10), 1115-1139. http://dx.doi. org/10.1108/01443571111172453

Moore, J. S., \& Reichert, A. K. (1983). An analysis of the financial management techniques currently employed by large US corporations. Journal of Business Finance \& Accounting, 10(4), 623-645. doi: 10.1111/j.1468-5957.1983.tb00456.x

Niven, P. R. (2006). Balanced Scorecard Step-by-step: Maximizing Performance and Maintaining Results. 2nd ed. John Wiley \& Sons, Inc.

Parmenter, D. (2007). Key Performance Indicators: Developing, Implementing and Using Winning KPI's. New Jersey: John Wiley \& Sons.

Pike, R. (1996). A longitudinal survey on capital budgeting practices. Journal of Business Finance \& Accounting, 23(1), 7992. doi: 10.1111/j.1468-5957.1996.tb00403.x

Ryan, P. A., \& Ryan, G. P. (2002). Capital budgeting practices of the Fortune 1000: How have things changed? Journal of Business and Management, 8(4), 355-364.

Sandahl, G., \& Sjögren, S. (2003). Capital budgeting methods among Sweden's largest groups of companies: The state of the art and a comparison with earlier studies. International Journal of Production Economics, 84(1), 51-69. doi:10.1016/ S0925-5273(02)00379-1

Simons, R. (2000). Performance Measurement \& Control Systems for Implementing Strategy: Text \& Cases. Prentice Hall, Inc.

Speckbacher, G., Bischof, J., \& Pfeiffer, T. (2003). A descriptive analysis on the implementation of Balanced Scorecards in German-speaking countries. Management Accounting Research, 14(4), 361-388. doi:10.1016/j.mar.2003.10.001

Stančić, P., Todorović, M., \& Čupić, M. (2012). Value-based management and corporate governance: A study of Serbian corporations. Economic Annals, 57(193), 93-112. doi:10.2298/ EKA1293093S

Todorović, M. (2010). Poslowno i finansijsko restrukturiranje preduzeća. Beograd. Republika Srbija: Ekonomski fakultet.

Truong, G., Partington, G., \& Peat, M. (2008). Cost of capital estimation and capital budgeting practice in Australia. Australian Journal of Management, 33(1), 95-121. doi: 10.1177/031289620803300106

Verma, S., Gupta, S., \& Batra, R. (2009). A survey of capital budgeting practices in corporate India. Vision: 
The Journal of Business Perspective, 13(3), 1-17. doi: $10.1177 / 097226290901300301$

\author{
Received on $13^{\text {th }}$ March 2015, \\ after revision, \\ accepted for publication on $6^{\text {th }}$ April 2015. \\ Published online on $21^{\text {st }}$ April 2015
}

Miroslav Todorovic is an Associate Professor at the Faculty of Economics, University of Belgrade, Belgrade, the Republic of Serbia, where he teaches the subjects of Business Finance, Corporate Restructuring and Auditing (undergraduate studies), and Issues in Corporate Finance, Issues in Auditing, Strategic Finance and Investment Management and Policy (master studies). He also teaches courses in the PhD studies at the Faculty of Economics in Belgrade and the Faculty of Economics in Kragujevac.

Djordje Kalicanin is an Associate Professor at the Faculty of Economics, University of Belgrade, Belgrade, the Republic of Serbia, where he acquired all his degrees. He teaches the courses in Strategic Management, Strategic Finance and Business Strategy. He is the author of articles in the scientific fields of strategic management, business planning and value-based management.

Aleksandra Nojkovic is an Associate Professor at the Faculty of Economics, University of Belgrade, Belgrade, the Republic of Serbia, on the courses in Econometrics and Time Series Analysis. She received her PhD at the Faculty of Economics, University of Belgrade. Her research interests are focused on macro-econometric modelling, the time series analysis and micro-econometrics. 


\title{
PRAKSE MERENJA PERFORMANSI U PREDUZEĆIMA U REPUBLICI SRBIJI
}

\author{
Miroslav Todorović*, Đorđe Kaličanin i Aleksandra Nojković \\ Ekonomski fakultet Univerziteta u Beogradu
}

Danas je u upotrebi veliki broj akronima poput EBIT (poslovni dobitak pre kamate i poreza), EBITDA (poslovni dobitak pre kamate, poreza i amortizacije), ROIC (stopa prinosa na investirani kapital), NPV (neto sadašnja vrednost), EVA (dodata ekonomska vrednost), IRR (interna stopa prinosa), ROE (stopa prinosa na sopstveni kapital), ROA (stopa prinosa na ukupna sredstva) i drugi, koji označavaju različita merila performansi. U praksi, menadžeri ne mogu i ne žele da primenjuju sva moguća merila, a izbor merila ne počiva nužno na njihovim teorijskim prednostima i nedostacima. $U$ cilju istraživanja prakse u Republici Srbiji anketirali smo finansijske menadžere 64 preduzeća. Značajno više se koriste merila zasnovana na diskontovanim novčanim tokovima, nego tradicionalna merila investicionog odlučivanja, $\mathrm{i}$ to najviše indeks rentabilnosti, praćen sa IRR i NPV. Period povraćaja se i dalje često koristi. Merila performansi preduzeća zasnovana na računovodstvenom dobitku i dalje su ubedljivo najzastupljenija. Ipak, prisustvo EVA i Balanced Scorecard (BSC) nije zanemarljivo, a velika preduzeća ih koriste značajno više od malih. Orijentacija ka tim merilima raste i sa stepenom internacionalizacije preduzeća. Na kraju, preduzeća koja koriste sofisticirana merila investicionog odlučivanja sklonija su da istovremeno koriste i sofisticirana merila performansi preduzeća.

Ključne reči: merenje performansi, merila investicionog odlučivanja, merila performansi preduzeća

\section{JEL Classification: G31, M21}

\section{UVOD}

Sve odluke preduzeća mogu se svrstati u tri kategorije: strategijske, taktičke i operativne. Strategijske odluke se odnose na poslovni portfolio, nivo vertikalne integracije $i$ širinu tržišta na kojima preduzeće želi da posluje. Taktičke odluke se odnose na investicione odluke kojima se sprovodi prethodno formulisana strategija. Operativne odluke se donose $u$

\footnotetext{
*Korespondencija: M. Todorović, Ekonomski fakultet Univerziteta u Beogradu, Kamenička 6, 11000 Beograd, Republika Srbija; e-mail: todorovic@ekof.bg.ac.rs
}

svakodnevnim operacijama, a za svrhe implementacije ranije odobrenih projekata i poslovnih planova. Krajnji kriterijum za sve odluke treba da bude maksimiranje vrednosti preduzeća. U pojednostavljenoj interpretaciji, sve odluke bi trebalo da se donose $\mathrm{u}$ smeru poboljšanja performansi preduzeća. Kako bi se performanse poboljšale, neophodno je odabrati ona merila ili metrike koje verodostojno ukazuju na nivo njihovog ostvarivanja. Otuda proizilazi veliki značaj merila performansi, jer se može upravljati samo onim što se može meriti. One su jasne smernice za planiranje, implementaciju i kontrolu poslovne 
strategije, projekata i svakodnevnih operacija. Merenje ne bi trebalo da bude cilj za sebe; ono mora imati neki smisao - ono treba da ukazuje na kvalitet ostvarenja ciljeva kao i sposobnost (ili inferiornost) preduzeća u ostvarenju datih ciljeva. Sveobuhvatna i koherentna struktura merila performansi naziva se sistemom merenja performansi - PMS (Performance Measurement System).

Veliki broj merila ili metrika se danas koristi u udžbenicima iz poslovnih finansija, strategijskog menadžmenta i strategijskih finansija, i to ne samo za merenje performansi preduzeća - CPM (Corporate Performance Metrics), već i za ocenu investicionih projekata - CBM (Capital Budgeting Metrics). Investiciono odlučivanje (Capital Budgeting) možemo posmatrati kao zasebnu metodologiju, ali na specifičan način i kao integralni deo PMS koji treba da omogući kreiranje vrednosti za akcionare. Moglo bi se reći da investiciono odlučivanje i PMS predstavljaju tačku povezivanja poslovnih finansija i sistema strategijskog menadžmenta, što predstavlja kamen temeljac strategijskih finansija. Oslanjajući se na projektovane buduće troškove i koristi, CBM predstavljaju vrstu očekivanih ili ex ante metrika, dok, na drugoj strani, CPM predstavljaju ex post merila ostvarenja. U poslovnoj praksi, menadžeri ne mogu i ne žele da primenjuju sve raspoložive metrike, a prilikom izbora onih koje će koristiti menadžeri se ne oslanjaju nužno na teorijske prednosti i nedostatke različitih metrika.

Cilj ovog istraživanja je da se stekne uvid u zastupljenost različitih merila performansi $u$ preduzećima u Republici Srbiji (RS), i na taj način doprinese suženju jaza između teorije i prakse poslovnih finansija. Istraživanje je sprovedeno $u$ formi ankete u kojoj su učestvovali menadžeri 64 preduzeća u RS, u periodu od marta do septembra 2014. Istraživanje je obuhvatilo širok spektar preduzeća, različitih karakteristika, u smislu njihove veličine, granske pripadnosti, zaduženosti, stepena diversifikacije i internacionalizacije, i drugo. To nam je omogućilo da, pored opšteg uvida u upotrebu različitih metrika, steknemo uvid u moguće razlike koje postoje u praksi između preduzeća sa različitim karakteristikama, na primer, između velikih preduzeća i malih preduzeća, između preduzeća koja su listirana na berzi i onih koja nisu listirana, između diversifikovanih i nediversifikovanih preduzeća i slično. U skladu sa ciljem istraživanja testirali smo tri hipoteze:

H1: Merila zasnovana na diskontovanim novčanim tokovima (DCF) su dominantna prilikom investicionog odlučivanja $\mathrm{u}$ preduzećima $\mathrm{u}$ Republici Srbiji.

H2: Prisustvo sofisticiranih merila i sistema merila perfomansi preduzeća nije zanemarljivo.

H3: Karakteristike preduzeća opredeljuju zastupljenost pojedinih merila performansi $u$ praksi.

Ovaj rad je organizovan na sledeći način. U narednom delu rada predstavili smo teorijsku osnovu i pregled literature vezane za predmet našeg istraživanja. Nakon toga smo prikazali metodologiju istraživanja. Na kraju rada smo diskutovali rezultate istraživanja i doneli nekoliko zaključaka.

\section{TEORIJSKA OSNOVA I PREGLED LITERATURE}

Sistemi merenja performansi - PMS predstavljaju formalizovane, na informacijama zasnovane rutinske postupke i procedure koje menadžeri koriste u cilju održavanja ili menjanja pravca biznisa (Simons, 2000, 4). Preporučljivo je da pre nego što budu uključene $u$ PMS, sve metrike prođu tri testa (Simons, 2000, 234240):

- da budu u skladu sa strategijom,

- da budu objektivne, i

- da budu usklađene sa vrhovnim ciljem maksimiranja vrednosti preduzeća.

Merila se mogu identifikovati u slučaju prošlih ostvarenja kao ključni indikatori rezultata - KRI (Key Results Indicators) ili, u slučaju mogućnosti i sposobnosti preduzeća da ostvari svoje ciljeve $\mathrm{u}$ budućnosti, kao ključni indikatori performansi - KPI (Key Performance Indicators) (Parmenter, 2007). Na ovaj način se ističe da sveobuhvatan PMS mora da ima i ex ante i ex post dimenziju. Osim toga, sveobuhvatan PMS 
treba da uključi i finansijska i nefinansijska merila performansi (Kaplan \& Norton, 1992; Niven, 2006). Nepostojanje PMS može imati izuzetno negativne efekte na formulaciju i implementaciju poslovne strategije (Micheli, Mura \& Agliati, 2011). Elaborirane pretpostvke su upravo bile korišćene kako bi se razvio sveobuhvatan PMS pod nazivom Balanced Scorecard (BSC) (Kaplan \& Norton, 1992; 1996). Taj PMS u jednom okviru obuhvata celu strukturu ciljeva i merila njihovog ostvarenja, zatim, zadatke i inicijative koje omogućavaju njihovo postignuće. Ciljevi, merila, zadaci i inicijative mogu da budu raspoređeni unutar neke od perspektiva, i to unutar: finansijske perspektive, perspektive potrošača, perspektive internih poslovnih procesa i pespektive učenja i rasta. Posebnu prednost ovog sistema predstavlja to što se isti izvodi iz strategijske mape - grafičkog prikaza poslovne strategije (Kaplan \& Norton, 2000).

Tradicionalni sistem performansi je bio pretežno zasnovan na računovodstvenim metrikama, kao što su neto dobitak, neto dobitak po akciji - EPS (Earnings Per Share), dobitak pre kamate i poreza - EBIT (Earnings Before Interest and Taxes), stopa prinosa na ukupna sredstva - ROA (Return On Assets), stopa prinosa na sopstveni kapital - ROE (Return On Equity) i druge, i na tradicionalnim CBM, kao što su period povraćaja - PP (Payback Period) i računovodstvena stopa prinosa - ARR (Accounting Rate of Return). Sa daljim razvojem poslovnih finansija pojavljuju se CBM zasnovane na diskontovanim novčanim tokovima - DCF (Discounted Cash Flow), kao što su neto sadašnja vrednost - NPV (Net Present Value), interna stopa prinosa - IRR (Internal Rate of Return) i indeks rentabilnosti - PI (Profitability Index). Konačno, da bi se ispoštovali zahtevi vlasnika (akcionara) za maksimiranjem vrednosti njihovog učešća u preduzećima, kreiran je koncept i metodologija menadžmenta zasnovanog na vrednosti - VBM (Value-Based Management). Prethodnica menadžmenta zasnovanog na vrednosti bilo je merenje zasnovano na vrednosti (Kaličanin, 2005). U drugoj polovini XX veka, ove metrike su se razvijale sporadično, a pun razvoj i upotreba otpočeti su u poslednjih nekoliko decenija $X X$ veka. Neke od najpoznatijih CPM razvijenih $u$ tim godinama su bile zasnovane na tržišnoj vrednosti preduzeća ili na konceptu ekonomskog dobitka ili, pak, na diskontovanim novčanim tokovima i to su: dodata tržišna vrednost - MVA (Market Value Added), dodata ekonomska vrednost - EVA (Economic Value Added), rezidualni dobitak, gotovinska stopa prinosa na investicije - CFROI (Cash Flow Return On Investment), dodata vrednost za akcionare - SVA (Shareholder Value Added), dodata gotovinska vrednost - CVA (Cash Value Added), višak prinosa, vrednost budućeg rasta - FGV (Future Growth Value) i druge. EVA se širom sveta pojavljuje kao jedna od najpopularnijih VBM metrika. Na drugoj strani, BSC predstavlja okvir za opis strategija koje kreiriaju vrednost (Speckbacher, Bischof \& Pfeiffer, 2003). Stoga ove metrike posmatramo kao komplementarne. BSC treba da dovede do kreiranja vrednosti koju eksplicitno pokazuje EVA. Takođe, EVA može da se koristi kao jedna od finansijskih metrika prilikom osmišljavanja BSC. Savremeni PMS, dakle, obično uključuju ne samo računovodstvene metrike, već i metrike zasnovane na vrednosti, i to ne samo finansijske, već i nefinansijske metrike.

Empirijska istraživanja u oblasti poslovnih finansija su, generalno, retka u RS, regionu, Centralnoj i Istočnoj Evropi i, uopšte, u zemljama u razvoju. $S$ druge strane, većinu istraživanja u SAD, Zapadnoj Evropi i drugim razvijenim zemljama čine istraživanja zasnovana na uzorcima sa velikim brojem preduzeća, uz upotrebu istorijskih podataka iz njihovih finansijskih izveštaja (knjigovodstvene vrednosti), podataka sa finansijskih tržišta (tržišne vrednosti), ili na bazi ukrštanja ta dva skupa podataka. Prednosti takvih istraživanja sastoje se $u$ dobroj statističkoj osmišljenosti i mogućnosti ponavljanja rezultata, a zbog velike veličine uzoraka, dobre dostupnosti, pouzdanosti i objektivnosti istorijskih podataka iz finansijskih izveštaja ili sa finansijskih tržišta. Glavni nedostatak ovih studija je taj što je na bazi njih teško zaključiti kako zaista $u$ poslovnoj praksi finansijski menadžeri donose odluke. Ovaj aspekt se može istražiti samo kroz „terenska istraživanja".

Zanimljivo je napomenuti da je nakon sporadičnih i relativno slabo zapaženih ovakih istraživanja u XX veku (na primer, Lintner, 1956; Moore \& Reichert, 1983; Jog \& Srivastava, 1995; Pike, 1996; George \& Chong, 1998; Kester, Chang, Echanis, Haikal, Isa, Skully, Tsui \& Wang, 1999), prvo istraživanje na terenu koje je skrenulo pažnju akademske javnosti publikovano tek 2001. godine od strane J. R. Graham-a i C. R. Harvey-a 
(2001). U tom, danas čuvenom, istraživanju, autori su prikupili 392 odgovora na preko 100 pitanja u anketi o investicionim i finansijskim odlukama koje donose finansijski menadžeri preduzeća. Cilj ovog istraživanja je bio da se uoči u kojoj meri se praksa poslovnih finansija (odluke koje donose menadžeri) poklapa sa teorijama poslovnih finansija (onim što su naučili na fakultetu). Opšti zaključak studije je da praksa značajno odstupa od teorije, posebno $\mathrm{u}$ domenu strukture kapitala, ali i u investicionom odlučivanju. Posle ove studije, brojna kasnija istraživanja imala su za cilj da potvrde ili opovrgnu nalaze J. R. Graham-a i C. R. Harvey-a, ili, pak, da praksu analiziraju iz neke nove perspektive (Ryan \& Ryan, 2002; Sandahl \& Sjögren, 2003; Brounen, De Jong \& Koedijk, 2004; Lazaridis, 2004; Dedi \& Orsag, 2007; Truong, Partington \& Peat, 2008; Verma, Gupta \& Batra, 2009; Baker, Dutta \& Saadi, 2011; Correia, 2012; Andrés, Fuente \& San Matin, 2014).

Prema našim saznanjima, opsežnija terenska istraživanja o upotrebi merila performansi u praksi preduzeća u RS nisu do sada sprovedena. Na osnovu sadržaja domaćih univerzitetskih udžbenika (Kaličanin, 2006; Todorović, 2010; Ivanišević, 2012; Đuričin, Janošević i Kaličanin, 2013) može se steći utisak da već na fakultetu menadžeri steknu dovoljno znanja da investicione projekte treba ocenjivati pre izvođenja, te da, zbog njihove očigledne superiornosti, menadžeri treba da koriste samo CBM zasnovane na diskontovanim novčanim tokovima, i to posebno NPV. Pored toga, oni bi trebalo da koriste CPM zasnovane na vrednosti, posebno EVA, ali i složenu i višedimenzionalnu tehniku BSC. Ipak, u nedostatku empirijskih istraživanja u RS, mogućnost da se menadžeri domaćih kompanija u RS ne ponašaju na ovaj „očekivani način” bila je u domenu „razumne sumnje".

\section{METODOLOGIJA ISTRAŽIVANJA}

Osnovni cilj istraživanja je bio da doprinese suženju jaza između teorije i prakse poslovnih finansija, sa fokusom na upotrebu merila performansi. Polazna tačka bila je sagledavanje mere u kojoj se teorijski koncepti zaista primenjuju od strane menadžera u poslovnoj praksi. U tom smislu, anketirali smo menadžere 64 preduzeća. Naša studija je obuhvatila relativno širok spektar preduzeća sa različitim karakteristikama u smislu njihove veličine, granske pripadnosti, listiranosti na berzi, zaduženosti, stepena diversifikacije i internacionalizacije, i drugo. To nam je omogućilo da, pored opšteg uvida u upotrebu različitih metrika, steknemo saznanje o mogućim razlikama koje postoje u praksi između preduzeća sa različitim karakteristikama, na primer, između velikih preduzeća i malih preduzeća, između preduzeća koja su listirana na berzi i onih koja nisu listirana, između diversifikovanih i nediversifikovanih preduzeća i slično.

Istraživanje je sprovedeno u periodu od marta do septembra 2014, prikupljanjem odgovora na upitnik na koji su odgovarali finansijski direktori - CFO (ili generalni direktori - CEO). Da bi se utvrdilo kako se različite karakteristike preduzeća odražavaju na praksu merenja performansi, sva preduzeća u uzorku smo podelili sedam puta na po dva poduzorka. Pregled preduzeća u uzorku dat je u Tabeli 1.

Tabela 1 Karakteristike uzorka

\begin{tabular}{|c|c|c|c|c|c|c|c|c|c|c|c|c|c|c|c|}
\hline & \multirow{3}{*}{ Uzorak } & \multicolumn{14}{|c|}{ Grupe preduzeća } \\
\hline & & \multicolumn{2}{|c|}{ Veličina } & \multicolumn{2}{|c|}{ Grana } & \multicolumn{2}{|c|}{ Internacion. } & \multicolumn{2}{|c|}{ Diversifik. } & \multicolumn{2}{|c|}{ Zaduženost } & \multicolumn{2}{|c|}{ Listiranost } & \multicolumn{2}{|c|}{ Profitabilnost } \\
\hline & & M & $\mathrm{V}$ & 0 & $P$ & $\mathrm{NI}$ & 1 & ND & D & $\mathrm{NZ}$ & Z & NL & $\mathrm{L}$ & NP & VP \\
\hline broj & 64 & 36 & 28 & 31 & 33 & 19 & 45 & 46 & 18 & 41 & 23 & 53 & 11 & 37 & 27 \\
\hline$\%$ & 100 & 56.25 & 43.75 & 48.44 & 51.56 & 29.69 & 70.31 & 71.88 & 28.13 & 64.06 & 35.94 & 82.81 & 17.19 & 57.81 & 42.19 \\
\hline
\end{tabular}


U velika preduzeća $(\mathrm{V})$ smo klasifikovali 28 preduzeća (ili $43.7 \%$ od ukupnog broja) sa godišnjim prihodima od preko 10 miliona evra². Prosečni prihodi po preduzeću u uzorku iznosili su 40,08 miliona evra, a prosečna ukupna aktiva 53,73 miliona evra. Više od polovine preduzeća iz uzorka $(51.56 \%)$ je pripadalo industriji hrane i pića (P). Većina preduzeća u uzorku (70.31\%) je ostvarivala deo prihoda na bazi prodaje $u$ inostranstvu (I). Osamnaest preduzeća svrstanih u diversifikovana preduzeća (D) su bila preduzeća koja su poslovala u tri ili više grana i/ili su više od $5 \%$ svojih prihoda ostvarivala van dominantnog biznisa. Razvrstali smo 23 preduzeća u zadužena $(\mathrm{Z})$, sa učešćem ukupnih dugova (kratkoročni i dugoročni krediti) u ukupnim sredstvima iznad $30 \%{ }^{3}$. Većina preduzeća $(85.81 \%)$ nije bila listirana (NL) na Beogradskoj ili bilo kojoj drugoj berzi. U profitabilna preduzeća (VP) ubrojali smo ona čiji je odnos neto dobitka prema ukupnoj aktivi (ROA) veći od $5 \%$.

U oblasti CBM, menadžerima smo ponudili sledeće modalitete: 1) NPV, 2) IRR, 3) indeks rentabilnosti $\mathrm{PI}^{4}$, 4) period povraćaja - $\mathrm{PP}, 5$ ) diskontovani period povraćaja - DPP 6) računovodstvena stopa prinosa - ARR. Sve ove metrike, a posebno one zasnovane na DCF, mogu se računati uz upotrebu različitih skupova projekcija (input-a). U tom smislu, pitali smo menadžere da li CBM računaju uz upotrebu isključivo jednog skupa input-a (projekcija) ili koriste više skupova input-a - scenarija (kao što su "dobar", "prosečan” i "„loš") - analiza scenarija, ili, pak, testiraju uticaj promena u pojedinim input-ima na izabranu metriku analiza senzitivnosti. $U$ delu ankete koji se odnosio na CPM, ispitanicima smo ponudili sledeće alternative: 1) računovodstveni dobitak (neto dobitak, EBIT, EBITDA, i drugo) kao apsolutne indikatore, 2) računovodstvene stope prinosa ( $\mathrm{ROE}$, stopa prinosa na investirani kapital - ROIC, ROA, i drugo), kao relativne indikatore, 3) EVA i 4) BSC. Učestalost upotrebe različitih metrika isptivali smo uz upotrebu Likertove skale sa pet podeoka (1-nikad, 5-uvek). U cilju otkrivanja eventualnih statistički značajnih razlika u praksama upotrebe različitih metrika između preduzeća sa različitim karakteristikama, koristili smo t-test za poređenje srednjih vrednosti između dva uzorka ${ }^{5}$.

Nedostatak istraživanja ovog tipa je taj što stavovi, uverenja i mišljenja ispitivanih menadžera ne predstavljaju nužno i njihovo stvarno ponašanje prilikom donošenja poslovnih odluka. Da bismo izbegli ovu manu, menadžere smo pitali da potvrde da su odnosnu metriku prihvatili $\mathrm{i}$ da je koriste $\mathrm{u}$ svojoj poslovnoj praksi, a ne da iznose svoje stavove o prednostima i/ili manama metrika. Takođe, zamolili smo anketirane menadžere da budu iskreni u svojim odgovorima (jer pojedinačni rezultati koji se odnose na njihova preduzeća neće biti objavljeni). Međutim, nismo mogli da proverimo u kojoj meri su oni zaista bili iskreni, i kakvo je stvarno stanje u primeni različitih merila performansi u poslovnoj praksi. Zbog toga smo, u cilju povećanja pouzdanosti odgovora, od menadžera prikupili podatke o matičnom broju, što smo kasnije koristili za prikupljanje dodatnih informacija o veličini preduzeća, zaduženosti i njihovoj profitabilnosti. Javno dostupni podaci sa sajta Agencije za privredne registre korišćeni su za te svrhe.

\section{REZULTATI I ANALIZA}

Rezultate istraživanja prezentovali smo u dva odeljka, za svaku od prethodno navedenih oblasti merila - CBM i CPM. U tabelama smo prikazli procente od ukupnog broja preduzeća koje koriste date metrike (uvek - 5 ili gotovo uvek - 4 na Likertovoj skali). Osim toga u tabelama su date i deskriptivne statistike, konkretno, srednje vrednosti za grupe i p-vrednosti obeležene na sledeći način: ${ }^{* * *},{ }^{* *},{ }^{*}$ - statistički značajna razlika na nivou $0,01,0,05$ i 0,10, respektivno.

\section{Merila u oblasti investicionog odlučivanja - CBM}

Naš prvi fokus se odnosio na otkrivanje učestalosti upotrebe različitih CMB. Rezultati ankete su prikazani na Slici 1.

Donekle iznenađujući nalaz je da tačno 3/4 preduzeća uvek ili gotovo uvek koriste indeks rentabilnosti - PI, ali i period povraćaja - PP $\mathrm{u}$ istom procentu (75\%). Potencijalna objašnjenja za ovako visok rang PI (koji je inače nešto slabije rangiran u udžbenicima) može biti želja menadžera da koriste relativnu metriku za koju se $\mathrm{u}$ udžbenicima navodi manje nedostataka nego što ih ima isto tako "relativna” metrika - IRR. Neka ranije sprovedena istraživanja (Graham \& Harvey, 


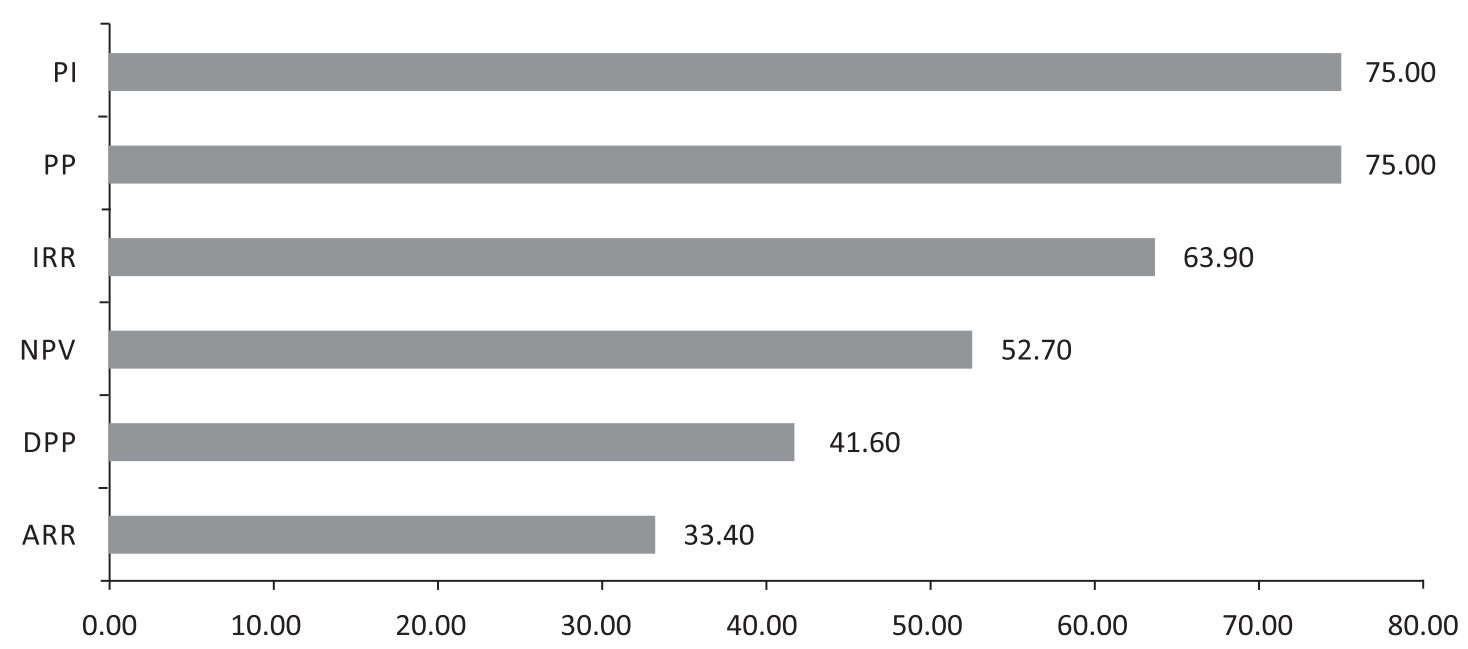

Slika 1 Procenat ispitanika koji uvek ili gotovo uvek koriste datu metriku

Izvor: Autori

2001), takođe, su pokazala sklonost menadžera ka „procentima” i relativnim merilima, ali uglavnom prema IRR 6 . Prema rezultatima našeg istraživanja IRR se, takođe, dosta koristi (63.9\%), ali tek na trećem mestu, iza PI i PP. Period povraćaja je dobro rangiran verovatno zbog svoje jednostavnosti i razumljivosti. Pošto menadžeri uglavnom koriste DCF metrike za ocenu investicionih projekata, verujemo da je period povraćaja u upotrebi kao dodatna metrika, što svakako ne predstavlja neku veliku grešku. Iako je u udžbenicima veliki prostor posvećen NPV, uz potenciranje superiornosti ove metrike, otkrili smo da ona nije i najrasprostranjenija u poslovnoj praksi. Tek nešto više od polovine menadžera (52.7\%) koristi ovaj metod uvek ili skoro uvek prilikom ocene investicionih projekata. Ohrabrujući rezultat našeg istraživanja je da se merila zasnovana na DCF smatraju važnijim od merila koja ne koriste DCF, što je zaključak sličan zaključku G. Kester-a et al (1999). Samo 8.3\% anketiranih menadžera ne koristi neku od DCF metrika - NPV, IRR ili PI - već se oslanja samo na tradicionalne CBM. Oko 19\% od ukupnog broja preduzeća koristi isključivo DCF metriku. Preostali deo uzorka, ili oko 73\% preduzeća, koristi kombinaciju tradicionalnih i DCF metrika. Još jedan ohrabrujući rezultat našeg istraživanja bio je da su DPP i ARR najmanje zastupljene metrike. Pošto se ove metrike ne karakterišu nekim posebnim kvalitetima, zaključujemo da je dobro što njihovo prisustvo u praksi slabo.

Glavna razlika u našim nalazima $u$ odnosu na ranije sprovedena istraživanja nije $\mathrm{u}$ visokom rejtingu PP (i IRR), već u odličnom rejtingu PI metrike. Rezultati našeg istraživanja poklapaju se sa nalazima G. Truong-a et al (2008), koji zaključuju da se u Australiji projekti uobičajeno ocenjuju uz upotrebu NPV, IRR i PP, i S. Verma et al (2009), koji su dobili veoma slične rezultate ispitujući poslovnu praksu u Indiji. Naši rezultati se blago razlikuju $u$ odnosu na rezultate istraživanja L. Dedi-a i S. Orsag-a (2007), koji su kod hrvatskih preduzeća otkrili sledeći prioritetni niz metrika: 1) IRR (59\%), 2) PP (56\%), i 3) NPV (42\%). Tu je i mala razlika u odnosu na Španiju, gde je najkorišćenija metrika bila PP, praćena sa IRR i NPV (Andrés et al, 2014). PP je bila najviše preferirana metrika na Kipru (Lazaridis, 2004). Osim toga, postoji razmimoilaženje sa rezultatima H. K. Baker-a et al (2011), koji su otkrili da u Kanadi postoji jaka sklonost ka NPV, praćena IRR i PP. Naše istraživanje pokazalo je veću sklonost ka IRR u odnosu na NPV. To je u suprotnosti i sa nalazima P. A. Ryan-a i G. P. Ryan-a (2002), koji su u svojoj anketi sprovedenoj sa kompanijama sa liste Fortune 1000 otkrili da NPV ima prednost nad IRR i drugim CBM. Konačno, imajući u vidu da manje od 10\% preduzeća 
ne koristi ni jednu od DCF metrika, možemo istaći da je i u RS upotreba DCF metrika već postala pravilo, kao što su to pokazali i V. M. Jog i A. Srivastava (1995), u slučaju kanadskih preduzeća.

U nastavku smo istraživali da li postoje razlike $u$ prisutnosti metrika između preduzeća različitih veličina, granskih pripadnosti, profitabilnosti, zaduženosti i slično. Rezultati ankete prikazani su u Tabeli 2.

Našli smo nekoliko statistički značajnih razlika između različitih grupa preduzeća. Menadžeri velikih preduzeća i listiranih preduzeća bili su lojalni „proverenim školskim” metrikama - NPV i IRR; javna (listirana) preduzeća koriste NPV u statistički značajno većoj meri od privatnih preduzeća (4.43 naspram 3.34), a velika preduzeća koriste IRR znatno više od malih (4.15 naspram 3.56). Možemo pretpostaviti da u slučaju listiranih preduzeća, percepcija menadžera o snažnom pritisku sa finansijskog tržišta da moraju da zarade prinos veći od prosečne ponderisane cene kapitala - WACC predstavljala glavni razlog za visoku "lojalnost" prema metrici koja koristi WACC. Osim toga, velika i listirana preduzeća obično imaju CFO (i CEO) sa najvišim stepenom obrazovanja u oblasti finansija. Pretpostavljamo da su oni spremni da primene ono što su naučili na fakultetu, odnosno, da primenjuju one metrike za koje veruju da su najverodostojnije. Diversifikovana preduzeća koriste više PI u odnosu na nediversifikovana (4.45 naspram 3.64). Razlog zbog čega diversifikacija podstiče na upotrebu „promišljenijih” metrika investicionog odlučivanja, verovatno leži u činjenici da je PI superioran metod za rangiranje projekata, kao i za poređenje između investicionih projekata u različitim poslovnim jedinicama u preduzećima sa više biznisa. Internacionalizacija jasno povećava tendenciju ka NPV i PP. Granska pripadnost i profitabilnost preduzeća nisu uticale na sklonost menadžera prilikom izbora između različitih metrika.

Iako nije na nivou statističke značajnosti, pažljivim ispitivanjem rezultata prezentovanih $u$ Tabeli 2 dolazi se do zanimljivog zaključka - sklonost ka upotrebi svih metrika veća je za velika, listirana ${ }^{7}$, internacionalizovana i diversifikovana preduzeća. Takva preduzeća (najčešće dobro poznata $u$ ekonomijama poput one u RS) obično angažuju finansijske menadžere i osoblje sa solidnim znanjima i dobrim obrazovanjem $u$ oblasti finansija, imaju dobre procedure investicionog odlučivanja i ocenjuju svoje investicione projekte uz angažman specijalizovanih konsultanata $\mathrm{u}$ oblasti finansija i računovodstva. $\mathrm{U}$ tom kontekstu, bilo bi iznenađujuće da ne koriste CBM. Tendencija ka korišćenju svih metrika, takođe, je bila veća kod zaduženih u odnosu na nezadužena preduzeća. Moguće objašnjenje možemo pronaći u disciplinujućoj ulozi dugova koja vodi rigoroznijem investicionom procesu. Dodatno, za očekivati je da takva preduzeća u svojim aplikacijama za finansijsku podršku banaka moraju uraditi investicione analize visokog kvaliteta.

Tabela 2 Učestalost upotrebe različitih merila investicionog odlučivanja - CBM

\begin{tabular}{|c|c|c|c|c|c|c|c|c|c|c|c|c|c|c|c|c|}
\hline \multirow{3}{*}{ Metrika } & \multicolumn{2}{|r|}{ Sva } & \multicolumn{14}{|c|}{ Srednja vrednost } \\
\hline & \multirow{2}{*}{$\begin{array}{l}\text { \% koji } \\
\text { koriste }\end{array}$} & \multirow{2}{*}{$\begin{array}{l}\text { Srednja } \\
\text { vrednost }\end{array}$} & \multicolumn{2}{|c|}{ Veličina } & \multicolumn{2}{|c|}{ Grana } & \multicolumn{2}{|c|}{ Internacion. } & \multicolumn{2}{|c|}{ Diversifik. } & \multicolumn{2}{|c|}{ Zaduženost } & \multicolumn{2}{|c|}{ Listiranost } & \multicolumn{2}{|c|}{ Profitabilnost } \\
\hline & & & M & V & 0 & $\mathrm{P}$ & $\mathrm{NI}$ & I & ND & M & V & 0 & $\mathrm{P}$ & $\mathrm{NI}$ & I & ND \\
\hline NP & 0 & 3.56 & 3.31 & 3.75 & 3.92 & 3.35 & 2.63 & $3.82 * *$ & 3.36 & 4.00 & 3.25 & 3.94 & 3.34 & $4.43^{* *}$ & 3.58 & 3.50 \\
\hline IRR & 63.90 & 3.89 & 3.56 & $4.15^{*}$ & 3.77 & 3.96 & 3.38 & 4.04 & 3.72 & 4.27 & 3.80 & 4.00 & 3.83 & 4.14 & 3.92 & 3.83 \\
\hline $\mathrm{PI}$ & 75.00 & 3.89 & 3.81 & 3.95 & 3.54 & 4.09 & 3.63 & 3.96 & 3.64 & $4.45^{*}$ & 3.70 & 4.13 & 3.79 & 4.29 & 4.04 & 3.58 \\
\hline PP & 75.00 & 4.08 & 3.75 & 4.35 & 4.15 & 4.04 & 3.50 & $4.25^{*}$ & 4.00 & 4.27 & 4.05 & 4.13 & 4.00 & 4.43 & 4.00 & 4.25 \\
\hline DPP & 41.60 & 3.17 & 2.81 & 3.45 & 2.85 & 3.35 & 2.50 & 3.36 & 3.08 & 3.36 & 3.10 & 3.25 & 3.00 & 3.86 & 3.21 & 3.08 \\
\hline ARR & 33.40 & 2.97 & 2.94 & 3.00 & 2.62 & 3.17 & 2.75 & 3.04 & 2.92 & 3.09 & 2.90 & 3.06 & 3.00 & 2.86 & 3.04 & 2.83 \\
\hline
\end{tabular}

Izvor: Autori 
Na neki način, bilo je sličnosti u našim rezultatima sa rezultatima D. Brounen-a et al (2004), koji otkrivaju da menadžeri u velikim američkim kompanijama uglavnom preferiraju DCF metrike. Slično poređenje može se učiniti sa rezultatima G. Sandahl-a i S. Sjögren-a (2003), koji iznose da velike kompanije češće koriste DCF metod nego male. Dalje, postoji delimična podudarnost sa rezultatima C. Correia-a (2012), koji otkriva da veća preduzeća preferiraju DCF merila, a da mala preduzeća koriste PP i ARR u većoj meri. Naš nalaz, baš kao i nalaz M. G. Danielson-a i J. A. Scott-a (2006), da mali biznisi obično koriste DCF metrike ređe nego velike kompanije, mogao bi se objasniti ograničenim obrazovanjem menadžera $u$ malim preduzećima i malobrojnošću finansijskog osoblja. Rezultate našeg istraživanja da listirana preduzeća preferiraju NPV možemo uporediti sa rezultatima $\mathrm{K}$. W. George-a i T. K. Chong-a (1998), koji su utvrdili da menadžeri listiranih preduzeća u Singapuru smatraju da su IRR i PP podjednako važna. Teško je objasniti veću tendenciju internacionalizovanih preduzeća u RS prema PP, kao što je teško objasniti veću prisutnost ove metrike kod velikih $\mathrm{u}$ odnosu na male kompanije na Kipru (Andrés et al, 2014).

U nastavku, želeli smo da ocenimo zastupljenost analize scenarija i/ili analize senzitivnosti (SA) u investicionom odlučivanju. Dati rezultati su prikazani u Tabeli 3 .

Ocena investicionih projekata se obično vrši uz upotrebu jednog skupa podataka i pretpostavki. Ipak, postoje preduzeća (44.4\%) koja nastoje da u razmatranje uzmu više scenarija. Utvrdili smo da su menadžeri velikih, diversifikovanih, zaduženih, javnih i profitabilnih preduzeća skloniji ka analizi scenarija, ali je razlika bila statistički značajna između preduzeća koja su internacionalizovala svoje poslovanje i onih koja i dalje svoje poslovne operacije izvode na domaćem tržištu (3.32 versus 2.38). Ova razlika mogla bi se objasniti različitim vrstama rizika koji su posledica internacionalizacije poslovanja. Obično postoji nekoliko nepoznanica koji se odnose na političke i pravne, ekonomske, socio-kulturološke, tehnološke i ekološke faktore u stranoj zemlji, kao i nepoznanice $u$ vezi poslovanja $u$ istoj grani, ali $u$ nekoj stranoj zemlji. Kompanija retko kada može tako dobro da poznaje sve konkurentne sile kao što je to slučaj na domaćem tržištu. Teže je predvideti poteze konkurenata i dinamiku rivalstva, planove kupaca o nabavkama i cenama koje su spremni da plate, namere dobavljača o prelasku na druge partnere, ulasku u vertikalnu integraciju i promeni cenovne strategije, buduće pritiske supstituta koji mogu doći iz drugih industrija, kao i pretnje ulazaka novih preduzeća u granu u kojoj se preduzeće nalazi. To je razlog zašto, pri oceni investicionih odluka, preduzeća sa internacionalizovanim poslovanjem obično uključuju promene jedne ili više pretpostavki o troškovima (rast), prodajnoj ceni (snižavanje), vreme otpočinjanja projekta (odlaganje), itd.

\section{Merila performansi preduzeća - CPM}

Drugi fokus istraživanja bio je da se otkrije učestalost upotrebe različitih merila performansi preduzeća CPM. Preciznije , očekujući dominantnu oslonjenost na računovodstvene metrike, bili smo zainteresovani da se uverimo u prisutnost EVA (ili ekonomskog dobitka) i BSC u preduzećima u RS. Dobili smo odgovore koje prikazujemo na Slici 2.

Tabela 3 Učestalost upotrebe analize scenarija/senzitivnosti

\begin{tabular}{|c|c|c|c|c|c|c|c|c|c|c|c|c|c|c|c|c|}
\hline & \multicolumn{2}{|r|}{ Sva } & \multicolumn{14}{|c|}{ Srednja vrednost } \\
\hline & \multirow{2}{*}{$\begin{array}{l}\% \text { koji } \\
\text { koriste }\end{array}$} & \multirow{2}{*}{$\begin{array}{l}\text { Srednja } \\
\text { vrednost }\end{array}$} & \multicolumn{2}{|c|}{ Veličina } & \multicolumn{2}{|c|}{ Grana } & \multicolumn{2}{|c|}{ Internacion. } & \multicolumn{2}{|c|}{ Diversifik. } & \multicolumn{2}{|c|}{ Zaduženost } & \multicolumn{2}{|c|}{ Listiranost } & \multicolumn{2}{|c|}{ Profitabilnost } \\
\hline & & & M & V & 0 & $\mathrm{P}$ & $\mathrm{NI}$ & I & ND & $M$ & V & 0 & $P$ & $\mathrm{NI}$ & I & ND \\
\hline SA & 44.40 & 3.11 & 2.75 & 3.40 & 3.15 & 3.09 & 2.38 & $3.32^{*}$ & 3.04 & 3.27 & 2.95 & 3.31 & 2.97 & 3.71 & 2.96 & 3.42 \\
\hline
\end{tabular}




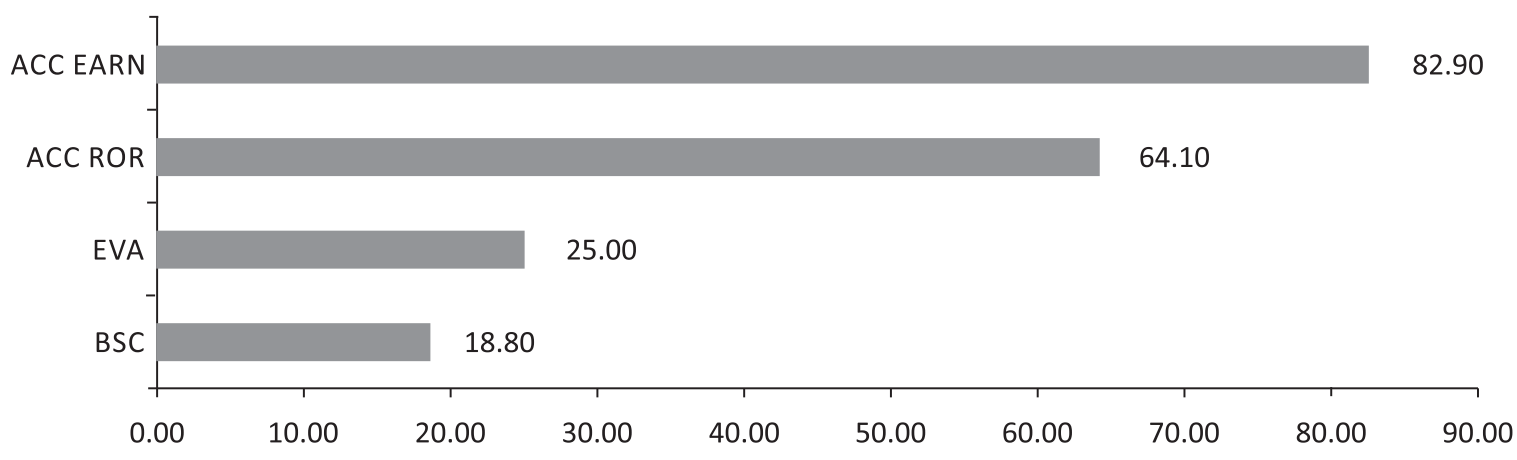

Slika 2 Procenat ispitanika koji uvek ili skoro uvek koriste datu metriku

Izvor: Autori

Nije iznenađujuće da su apsolutne mere računovodstvenog dobitka (ACC EARN) i dalje najčešće u poslovnoj praksi u RS. Preko 4/5 menadžera $(82.9 \%)$ se oslanjalo na njih kad se sagledavaju/ocenjuju performanse preduzeća. Relativno je visoko i prisustvo relativnih računovodstvenih metrika (ACC ROR) kao što su ROA, ROE, ROIC i drugih; oni su u upotrebi u oko 2/3 preduzeća. U odnosu na računovodstvene metrike prisutna je drastična razlika u zastupljenosti savremenih metrika (ili PMS), odnosno EVA i BSC. EVA se koristi češće nego BSC. Naizgled relativno slabo korišćena EVA ipak je u stalnoj ili skoro stalnoj upotrebi u 1/4 od ukupnog broja preduzeća. U odnosu na ono što je otkriveno $\mathrm{u}$ ranijim studijama prakse $\mathrm{u}$ preduzećima u RS (Stančić, Todorović \& Čupić, 2012; Domanovic, 2013), ovo predstavlja očigledni korak napred. Možemo zaključiti da VBM počinje da biva prisutan ne samo deklarativno, već i da je on podržan upotrebom dokazane metodologije. Osim toga, još jedan ohrabrujući rezultat je prisustvo BSC u nešto manje od 1/5 kompanija (18.8\%). Postoje različiti tipovi implementacije BSC. Najjednostavniji podrazumeva samo kombinaciju finansijskih i nefinansijskih merila, drugi tip uključuje strategijske mape, a treći podrazumeva povezivanje sistema kompenzacija i BSC. Zbog dizajna našeg istraživanja nije bilo moguće testirati koji oblik BSC koriste preduzeća u RS, ali oni barem koriste neku smislenu mešavinu finansijskih i nefinansijskih merila. Pretpostavljamo da su EVA i BSC bili manje prisutni jer su manje poznati, mnogo kompleksniji za upotrebu i, za razliku od računovodstvenih metrika, oni nisu direktan rezultat vođenja zakonski propisanih računovodstvenih evidencija. Osim toga, efektivnost tih metrika i dalje je predmet istraživanja. Teoretski, one su skoro savršene, ali, s druge strane, postoji mnogo ograničenja i problema u njihovoj praktičnoj upotrebi. Verovatno te nesavršenosti čine da mnogi domaći menadžeri nisu spremni da ih isprobaju bez oklevanja. Pored toga, moderne metrike često se promovišu od strane globalnih konsalting kompanija. U RS, osim u oblasti revizije, konsultantska industrija nije privukala neke velike globalne igrače koji bi promovisali ove metrike. Možda i ne postoji dovoljno veliki broj preduzeća koja bi finansijski mogla sebi da priušte korišćenje ovih metrika. Naime, primena tih metrika je olakšana upotrebom software-a koji su obično preskupi za domaća preduzeća. Konačno, menadžeri su prilično svesni mogućih visokih naknada za patentirane metrike. Svi ovi faktori ozbiljno ograničavaju njihovu primenu i čine da su menadžeri lojalniji računovodstvenim metrikama.

Nastavili smo analizu pokušavajući da uočimo da li postoji bilo kakva razlika između prakse u merilima performansi preduzeća između različitih grupa kompanija. Rezultati su prikazani u Tabeli 4.

Rezultati ankete prikazani u Tabeli 4 pokazuju da zastupljenost različitih metrika varira značajno između preduzeća u zavisnosti od veličine, nivoa internacionalizacije i profitabilnosti. 
Tabela 4 Učestalost korišćenja različitih merila performansi preduzeća - CPM

\begin{tabular}{|c|c|c|c|c|c|c|c|c|c|c|c|c|c|c|c|c|}
\hline \multirow{3}{*}{ Metrika } & \multicolumn{2}{|c|}{ Sva } & \multicolumn{14}{|c|}{ Srednja vrednost } \\
\hline & \multirow{2}{*}{$\begin{array}{l}\text { \% koji } \\
\text { koriste }\end{array}$} & \multirow{2}{*}{$\begin{array}{l}\text { Srednja } \\
\text { vrednost }\end{array}$} & \multicolumn{2}{|c|}{ Veličina } & \multicolumn{2}{|c|}{ Grana } & \multicolumn{2}{|c|}{ Internacion. } & \multicolumn{2}{|c|}{ Diversifik. } & \multicolumn{2}{|c|}{ Zaduženost } & \multicolumn{2}{|c|}{ Listiranost } & \multicolumn{2}{|c|}{ Profitabilnost } \\
\hline & & & M & V & 0 & $P$ & $\mathrm{NI}$ & I & ND & M & V & 0 & $P$ & $\mathrm{NI}$ & I & HP \\
\hline $\begin{array}{l}\text { ACC } \\
\text { EARN }\end{array}$ & 82.90 & 4.31 & 4.00 & $4.71^{* * *}$ & 4.29 & 4.33 & 4.11 & 4.40 & 4.30 & 4.33 & 4.22 & 4.48 & 4.28 & 4.45 & 4.38 & 4.22 \\
\hline $\begin{array}{l}\text { ACC } \\
\text { ROR }\end{array}$ & 64.10 & 3.61 & 3.11 & $4.25^{* * *}$ & 3.68 & 3.65 & 2.63 & $4.02 * * *$ & 3.54 & 3.78 & 3.46 & 3.87 & 3.58 & 3.73 & 3.95 & $3.15^{* *}$ \\
\hline EVA & 25.00 & 2.30 & 1.78 & $2.96 * * *$ & 2.26 & 2.33 & 1.58 & $2.60 * * *$ & 2.30 & 2.28 & 2.32 & 2.26 & 2.36 & 2.00 & 2.49 & 2.04 \\
\hline BSC & 18.80 & 2.22 & 1.92 & $2.61 * *$ & 2.1 & 2.33 & 1.79 & $2.40^{*}$ & 2.28 & 2.06 & 2.17 & 2.30 & 2.13 & 2.64 & 2.24 & 2.19 \\
\hline
\end{tabular}

Izvor: Autori

EVA se statistički značajno više koristi $\mathrm{u}$ velikim nego u malim preduzećima (srednja vrednost od 2.96 naspram 1.78) i u preduzećima koja ostvaruju prihode na inostranim tržištima nego $u$ preduzećima koja prodaju samo na domaćem tržištu (2.60 naspram 1.58). Našli smo sličnu situaciju sa upotrebom BSC u velikim (2.61 za velika, 1.92 za mala preduzeća) i internacionalizovanim preduzećima (2.40 za internacionalizovana naspram 1.79 za neinternacionalizovana). EVA je najmanje zastupljena u preduzećima koja generišu prihode isključivo na domaćem tržištu (srednja vrednost od 1.58), a najviše $\mathrm{u}$ velikim kompanijama (2.96). BSC se najviše koristi u listiranim preduzećima (2.64), a najmanje je prisutan u preduzećima koja ostvaruju prihode isključivo na domaćem tržištu (1.79). Nešto veća prihvaćenost BSC od strane listiranih preduzeća mogla bi poticati iz njihove svesti o suštini BSC.

$\mathrm{Na}$ osnovu dosadašnjih rezultata, mogli bismo zaključiti da orijentacija preduzeća ka sofisticiranim merilima performansi raste sa veličinom i nivoom internacionalizacije preduzeća. Pored toga, otkrili smo da velika preduzeća i internacionalizovana preduzeća koriste u većoj meri i relativna računovodstvena merila $\mathrm{u}$ poređenju sa malim i neinternacionalizovanim preduzećima. Konačno, velika preduzeća su, takođe, sklonija korišćenju i apsolutnih računovodstvenih merila, nego mala preduzeća. Velika preduzeća, dakle, koriste sve metrike u statistički značajno većoj meri nego mala preduzeća. Veća prihvaćenost svih metrika u velikim kompanijama mogla bi se svakako objasniti razvijenošću procesa i kvalitetom kadrova $u$ odeljenjima finansija kontrolinga i planiranja u ovim preduzećima $\mathrm{u}$ odnosu na mala preduzeća. PMS se obično razvija u tim odeljenjima. Ona predstavljaju centralne jedinice koje komuniciraju sa mnogim drugim odeljenjima $u$ vezi PMS i njegovim delovima i komponentama. Donekle neobično otkriće je da preduzeća sa većom profitabilnošću imaju tendenciju da manje koriste relativne računovodstvene metrike (3.15 versus 3.95). Ostale karakteristike preduzeća nisu imale uticaj na izbor merila performansi.

$\mathrm{Na}$ temu prihvaćenosti različitih metrika sprovedno je nekoliko studija u nekoliko zemalja. Rezultati su šaroliki i treba ih uzeti sa rezervom. U istraživanju sprovedenom u SAD, u 1998, vezanom za prihvaćenost EVA od strane komanija sa liste Fortune 500, otkriveno je da samo 9.4\% kompanija eksplicitno navodi da koriste EVA kao merilo performansi, kao alat „u trendu" (Abdeen \& Haight, 2002). Pozivajući se na istraživanje koje je sproveo Institut upravljačkih računovođa, M. W. Meyer (2004) tvrdi da je 1995. godine 18\% najvećih američkih kompanija koristilo EVA, a u 1996. godini „34\% kompanija zapravo koristi EVA"! Prema istraživanju koje je sproveo magazin Business Finance8 u 2004. godini 33\% kompanija koristi BSC, a 18\% EVA. Međutim, velike kompanije (sa prihodima od preko 1 milijardu dolara) koriste BSC čak u 59\% slučajeva, a 33\% njih koristi EVA. G. Speckbacher et al (2003) su utvrdili da oko 1/4 (26\%) najvažnijih listiranih kompanija u zemljama nemačkog govornog područja (Nemačka, Austrija i Švajcarska) koristi BSC, a u većini je korišćen najjednostavniji tip. Oni su, takođe, primetili da su veće kompanije (mereno 
brojem zaposlenih) bile sklonije da koriste BSC, kao i da, posmatrano sa stanovišta grane, maloprodajna preduzeća značajno manje koriste ovo merilo. M. Marc, D. Peljhan, N. Ponikvar, A. Sobota i M. Tekavcic (2010) su utvrdili da čak $68 \%$ velikih kompanija u Sloveniji koristi BSC ili neke druge integrisane PMS. Međutim, upoređujući rezultate njihova dva istraživanja koja su sprovedena u 2003. i 2008. godini, oni su primetili da preduzeća u Sloveniji još uvek radije koriste finansijska merila u odnosu na nefinansijska. Još jedno istraživanje o upotrebi BSC u okviru malih preduzeća sprovedeno u Velikoj Britaniji i na Kipru (Giannopoulos, Holt, Khansalar \& Cleanthous, 2013), pokazuje da je svesnost o BSC bila znatno veća na Kipru (45\%) nego u Velikoj Britaniji (20\%). Ali, procenat „svesnih" preduzeća koja zaista u praksi koriste BSC bio je isti u obe zemlje (25\%).

Na kraju, zapitali smo se da li postoji smislen odnos u korišćenju CBM i korišćenju CPM. Očekivali smo da kompanije koje više koriste EVA ili BSC, takođe, više koriste i DCF metrike $\mathrm{u}$ oblasti investicionog istraživanja. Rezultati su prikazani u Tabeli 5.

Tabela 5 Simultana upotreba merila investicionog odlučivanja i merila performansi preduzeća

\begin{tabular}{l|cc}
\hline \multirow{2}{*}{ Metrike } & \multicolumn{2}{|c}{ EVA/BSC } \\
& Ne koriste & Koriste \\
\hline NPV & 3.36 & 4.00 \\
IRR & 3.76 & 4.18 \\
PI & 3.88 & 3.91 \\
PP & 4.82 & $3.76^{* * *}$ \\
DPP & 3.91 & $2.84^{* *}$ \\
ARR & 2.96 & 3.00 \\
& $\ldots$ & \\
SA & 2.84 & $3.73^{*}$ \\
\hline
\end{tabular}

Izvor: Autori

Preduzeća koja koriste savremena merila performansi, takođe, koriste metrike zasnovane na diskontovanim novčanim tokovima (NPV, IRR i PI) u većoj meri, ali ta razlika nije statistički značajna. Međutim, ova preduzeća koriste manje tradicionalne CBM, odnosno, PP i DPP, u statistički značajnoj meri. Konačno, takođe smo otkrili da menadžeri ovih preduzeća imaju veću sklonost ka analizi scenarija.

\section{ZAKLJUČAK}

Merila performansi preduzeća i merila $u$ oblasti investicionog odlučivanja treba posmatrati kao komplementarne podsisteme sistema za merenje performansi. Njihov razvoj omogućava sveobuhvatne napore za usmeravanje preduzeća ka maksimiranju vrednosti za akcionare (vlasnike). Sproveli smo terensku studiju sa dva glavna cilja: da vidimo koje metrike koriste menadžeri $u$ preduzećima u RS i da uočimo kako karakteristike preduzeća utiču na taj izbor. Glavno ograničenje studije na terenu je da moramo pretpostaviti da su menadžeri iskreni $u$ svojim odgovorima i da rade ono što kažu da rade. Zbog pristrastnosti menadžera da daju društveno prihvatljive odgovore, studije zasnovane na anketama obično precenjuju zastupljenost sofisticiranih merila.

Možemo istaći nekoliko zaključaka. U vezi sa prvom hipotezom, zaključili smo da je DCF metrika u oblasti investicionog odlučivanja dominantna u preduzećima u RS. Takođe, saznali smo da menadžeri preduzeća u RS koriste PI i PP u najvećoj meri, dok je IRR preferisani metod $u$ odnosu na NPV (to samo nije bio slučaj kod listiranih kompanija). Orijentacija menadžera prema PI je za pohvalu, jer PI zadržava najveći deo prednosti NPV, dok je $\mathrm{u}$ isto vreme relativno merilo. Zbog nedovoljnog poznavanja inostranog tržišta, preduzeća koja ostvaruju prihode i $u$ inostranstvu imaju tendenciju da više koriste analizu senzitivnosti od preduzeća koja poslovne operacije obavljaju samo na domaćem tržištu. Računovodstveni dobitak i računovodstvene stope prinosa i dalje su dominantne $u$ odnosu na savremene metrike. Prisustvo sofisticiranih merila i sistema merila performansi nije zanemarljivo, čime smo potvrdili drugu hipotezu. Primećeno je da velika preduzeća koriste EVA i BSC više od malih preduzeća. Mala preduzeća koriste svaku od ispitivanih merila performansi preduzeća manje od velikih preduzeća u statistički značajnoj meri. Postoji 
očigledno veća zastupljenost EVA i BSC kod preduzeća sa internacionalizovanim poslovanjem. Konačno, preduzeća koje ne koriste moderna merila i sisteme performansi, takođe, su sklona da signifikantno više koriste tradicionalne metrike investicionog odlučivanja koja nisu zasnovana na DCF. Napred objašnjene razlike u upotrebi različitih merila izmedju preduzeća različitih karakteristika jasno su potvrdile treću hipotezu ovog istraživanja.

Ovo istraživanje je stvorilo mogućnosti za nekoliko budućih istraživanja. Longitudinalne studije su logično (i često) proširenje ovakve vrste istraživanja zbog verovatnoće da se pomenute prakse menjaju $\mathrm{u}$ vremenu. Još jedan vrlo zanimljivi pravac daljeg istraživanja može da bude istovremeno istraživanje $\mathrm{u}$ više zemalja $\mathrm{u}$ regionu, jer mnoga od anketiranih preduzeća imaju svoje subsidijare u tim zemljama, a isti imaju izvesnu autonomiju $\mathrm{u}$ procesu investicionog odlučivanja. Konačno, posebna studija može se sprovesti sa svrhom ispitivanja da li korišćenje sofisticiranih metrika može voditi boljim finansijskim performansama preduzeća.

\section{ENDNOTE}

1 U literaturi je uobičajena upotreba termina metode investicionog odlučivanja, ali nije retka ni upotreba termina metrike investicionog odlučivanja (na primer, Brigham \& Houston, 2012, 400) ili merila investicionog odlučivanja.

2 Svi kvantitativni podaci se odnose na datum 31.12.2013, i preuzeti su sa sajta Agencije za privredne registre: http:// www. apr. rs.

3 Istu granicu su koristili i J. R. Graham i C. R. Harvey (2001).

4 Racio rentabilnosti poznat je i kao cost-benefit racio.

5 Ovde smo se vodili zaključkom do kojeg su došli J. C. F. de Winter i D. Dodou (2010), koji su otkrili da se t-test može koristiti umesto Mann-Whitney-Wilcoxon testa, budući da imaju ekvivalentnu objašnjujuću moć.

6 Ovakav stav se obično tumači kao pogrešna orijentacija zato što se NPV u udžbenicima opisuje kao superioran metod. Ipak, može se reći da primedba nije na mestu zato što menadžeri ne moraju nužno da se sećaju svih lekcija koju su savladavali tokom svojih studija.
7 Osim za ARR.

8 http://businessfinancemag.com/planning-budgeting-ampreporting/performance-managements-growing-pains, posećen 28.02.2015.

\section{REFERENCE}

Abden, A. M., \& Haight, T. G. (2002). A Fresh Look At Economic Value Added: Empirical Study Of The Fortune Five-Hundred Companies. The Journal of Applied Business Research, 18(2), 27-36.

Andrés, P. de, Fuente, G. de, \& San Martin, P. (2014). Capital budgeting practices in Spain. Business Research Quarterly, (Article in press), http://dx.doi.org/10.1016/j.brq.2014.08.002.

Baker, H. K., Dutta, S., \& Saadi, S. (2011). Corporate finance practices in Canada: Where do we stand? Multinational Finance Journal, 15(3/4), 157-192.

Brigham, E. F., \& Houston, J. F. (2012). Fundamentals of Financial Management. Concise Edition, Cengage Learning.

Brounen, D., de Jong, A., \& Koedijk, K. (2004). Corporate finance in Europe: Confronting theory with practice. Financial Management, 33(4), 71-101.

Correia, C. (2012). Capital budgeting practices in South Africa: A review. South African Journal of Economic and Management Sciences, 43(2), 11-29.

Danielson, M. G., \& Scott, J. A. (2006). The capital budgeting decisions of small businesses. Journal of Applied Finance, $16(2), 45-56$

Dedi, L., \& Orsag, S. (2007). Capital Budgeting Practices: A Survey of Croatian Firms. South East European Journal of Economics and Business, 2(1), 59-67. doi: 10.2478/v10033-0070016-y

de Winter, J. C. F., \& Dodou, D. (2010). Five-point Likert items: $\mathrm{t}$ test versus Mann-Whitney-Wilcoxon. Practical Assessment, Research E Evaluation, 15(11), 1-16.

Domanovic, V. (2013). The effectiveness of the performance measurement in terms of contemporary business environment. Economic Horizons, 15(1), 33-46. doi:10.5937/ ekonhor1301031D

Đuričin, D., Janošević, S., i Kaličanin, Đ. (2013). Menadžment i strategija. Beograd, Republika Srbija: Ekonomski fakultet.

Graham, J. R., \& Harvey, C. R. (2001). The theory and practice of corporate finance: Evidence from the field. Journal of Financial Economics, 60(2-3), 187-243. doi:10.1016/S0304- 
405X(01)00044-7

George, K. W., \& Chong, T. K. (1998). Capital budgeting practices of listed firms in Singapore. Singapore Management Review, 20(1), 9-23.

Giannopoulos, G., Holt, A., Khansalar, E., \& Cleanthous, S. (2013). The Use of The Balanced Scorecard in Small Companies. International Journal of Business and Management, 8(14), 1-22. doi: 10.5539/ijbm.v8n14p1

Ivanišević, M. (2012). Poslovne finansije. Beograd, Republika Srbija: Ekonomski fakultet.

Jog, V. M., \& Srivastava, A. (1995). Capital Budgeting Practices in Corporate Canada. Financial Practice and Education, 5(2), 37-43.

Kaličanin, Đ. (2005). Merenje performansi zasnovano na vrednosti. Ekonomika preduzeća, 53(3-4), 91-100.

Kaličanin, Đ. (2006). Menadžment vrednosti preduzeća. Beograd. Republika Srbija: Ekonomski fakultet.

Kaplan, R. S., \& Norton, D. P. (1992). The balanced scorecard measures that drive performance. Harvard Business Review, 70(1), 71-79.

Kaplan, R. S., \& Norton, D. P. (1996). The Balanced Scorecard: Translating Strategy into Action. Boston, Massachusetts: Harvard Business School Press.

Kaplan, R. S., \& Norton, D. P. (2000). Having Trouble with Your Strategy? Then Map It! Harvard Business Review, 78(5), 167176.

Kester, G., Chang, R. P., Echanis, E. S., Haikal, S., Isa, M. Md., Skully, M. T., Tsui, K. C., \& Wang, C. J. (1999). Capital budgeting practices in the Asia-Pacific region: Australia, Hong Kong, Indonesia, Malaysia, Philippines, and Singapore. Financial Practice and Education, 9(1), 25-33.

Lazaridis, I. (2004). Capital budgeting Practices: A survey in the Firms in Cyprus. Journal of Small Business Management, 42(4), 427-433. doi: 10.1111/j.1540-627X.2004.00121.x

Lintner, J. (1956). Distribution of incomes of corporations among dividends, retained earnings, and taxes. The American Economic Review, 46(2), 97-113.

Marc, M., Peljhan, D., Ponikvar, N., Sobota, A., \& Tekavcic, M. (2010). Performance Measurement in Large Slovenian Companies: An Assessment of Progress. International Journal of Management \& Information Systems, 14(5), 129-139.

Meyer, M. W. (2004) Finding performance: The new discipline in management, In A. Neely (Ed.). Business performance measurement: Theory and practice (pp. 113-124). New York, NY: Cambridge University Press.

Micheli, P., Mura, M., \& Agliati, M. (2011). Exploring the roles of performance measurement systems in strategy implementation: The case of a highly diversified group of firms. International Journal of Operations $\mathcal{E}$ Production Management, 31(10), 1115-1139. http://dx.doi. org/10.1108/01443571111172453

Moore, J. S., \& Reichert, A. K. (1983). An analysis of the financial management techniques currently employed by large US corporations. Journal of Business Finance \& Accounting, 10(4), 623-645. doi: 10.1111/j.1468-5957.1983.tb00456.x

Niven, P. R. (2006). Balanced Scorecard Step-by-step: Maximizing Performance and Maintaining Results. 2nd ed. John Wiley \& Sons, Inc.

Parmenter, D. (2007). Key Performance Indicators: Developing, Implementing and Using Winning KPI's. New Jersey: John Wiley \& Sons.

Pike, R. (1996). A longitudinal survey on capital budgeting practices. Journal of Business Finance \& Accounting, 23(1), 7992. doi: 10.1111/j.1468-5957.1996.tb00403.x

Ryan, P. A., \& Ryan, G. P. (2002). Capital budgeting practices of the Fortune 1000: How have things changed? Journal of Business and Management, 8(4), 355-364.

Sandahl, G., \& Sjögren, S. (2003). Capital budgeting methods among Sweden's largest groups of companies: The state of the art and a comparison with earlier studies. International Journal of Production Economics, 84(1), 51-69. doi:10.1016/ S0925-5273(02)00379-1

Simons, R. (2000). Performance Measurement \& Control Systems for Implementing Strategy: Text \& Cases. Prentice Hall, Inc.

Speckbacher, G., Bischof, J., \& Pfeiffer, T. (2003). A descriptive analysis on the implementation of Balanced Scorecards in German-speaking countries. Management Accounting Research, 14(4), 361-388. doi:10.1016/j.mar.2003.10.001

Stančić, P., Todorović, M., \& Čupić, M. (2012). Value-based management and corporate governance: A study of Serbian corporations. Economic Annals, 57(193), 93-112. doi:10.2298/ EKA1293093S

Todorović, M. (2010). Poslovno i finansijsko restrukturiranje preduzeća. Beograd. Republika Srbija: Ekonomski fakultet.

Truong, G., Partington, G., \& Peat, M. (2008). Cost of capital estimation and capital budgeting practice in Australia. Australian Journal of Management, 33(1), 95-121. doi: $10.1177 / 031289620803300106$ 
Verma, S., Gupta, S., \& Batra, R. (2009). A survey of capital budgeting practices in corporate India. Vision:
The Journal of Business Perspective, 13(3), 1-17. doi: $10.1177 / 097226290901300301$
Primljeno 13. marta, 2015, nakon revizije, prihvaćeno za publikovanje 6. aprila 2015.

Elektronska verzija objavljena 21. aprila 2015.

Miroslav Todorović je vanredni profesor na Ekonomskom fakultetu Univerziteta u Beogradu, na nastavnim predmetima: Poslovne finansije, Restrukturiranje preduzeća i Revizija (osnovne akademske studije), i Specifični problemi poslovnih finansija, Strategijske finansije i Upravljanje investicijama i investiciona politika (master akademske studije). Predaje i na doktorskim akademskim studijama, na ekonomskim fakultetima Univerziteta u Beogradu i Univerziteta u Kragujevcu.

Đorđe Kaličanin je vanredni profesor na Ekonomskom fakultetu Univerziteta u Beogradu, na kojem je stekao sva svoja zvanja. Na osnovnim akademskim studijama predaje Strategijski menadžment, a na master akademskim studijama, Strategijske finansije i Poslovnu strategiju. Autor je članaka iz oblasti strategijskog menadžmenta, poslovnog planiranja i menadžmenta zasnovanog na vrednosti.

Aleksandra Nojković je vanredni profesor na Ekonomskom fakultetu Univerziteta u Beogradu, na nastavnim predmetima Ekonometrija i Analiza vremenskih serija. Doktorirala je na Ekonomskom fakultetu Univerzitetu u Beogradu. Polja njenog naučnog istraživanja su makroekonometrijsko modeliranje, analiza vremenskih serija i mikroekonometrija. 


\title{
PRACTICES OF PERFORMANCE MEASUREMENT IN COMPANIES IN THE REPUBLIC OF SERBIA
}

\author{
Miroslav Todorovic, Djordje Kalicanin and Aleksandra Nojkovic \\ Faculty of Economics, University of Belgrade, Belgrade, The Republic of Serbia
}

\begin{abstract}
A large number of acronyms which indicate different performance metrics, such as EBIT (Earnings Before Interest And Taxes), EBITDA (Earnings Before Interest, Taxes, Depreciation, And Amortization), ROIC (Return On Invested Capital), NPV (Net Present Value), EVA (Economic Value Added), IRR (Internal Rate Of Return), ROE (Return On Equity), ROA (Return On Assets) etc. are in use nowadays. In practice, managers cannot and do not want to apply all of these metrics and managers' choice does not necessarily rely on what theory emphasizes as their advantages and disadvantages. We surveyed 64 CFOs in order to explore the corporate practice in the Republic of Serbia. The DCF-based capital budgeting metrics are dominant compared to the traditional metrics, and the one that is used the most is the profitability index, only to be followed by the IRR and the NPV. The Payback Period is yet frequently used. The earningsbased corporate performance metrics are still the most important. However, the presence of EVA and the balanced scorecard is not negligible. Large companies use them significantly more than small companies. The orientation towards EVA and the balanced scorecard increases with the internationalization of a firm as well. Finally, companies using sophisticated capital budgeting metrics are prone to using sophisticated corporate performance metrics.
\end{abstract}

Keywords: performance measurement, capital budgeting metrics, corporate performance metrics 